
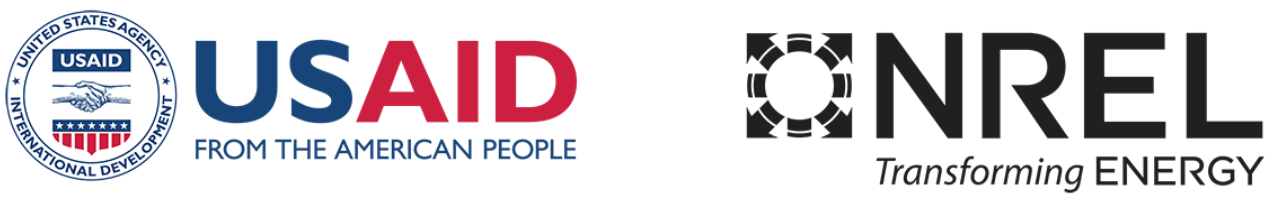

\title{
Foundations of an Electric Mobility Strategy for the City of Mexicali State of Baja California, Mexico
}

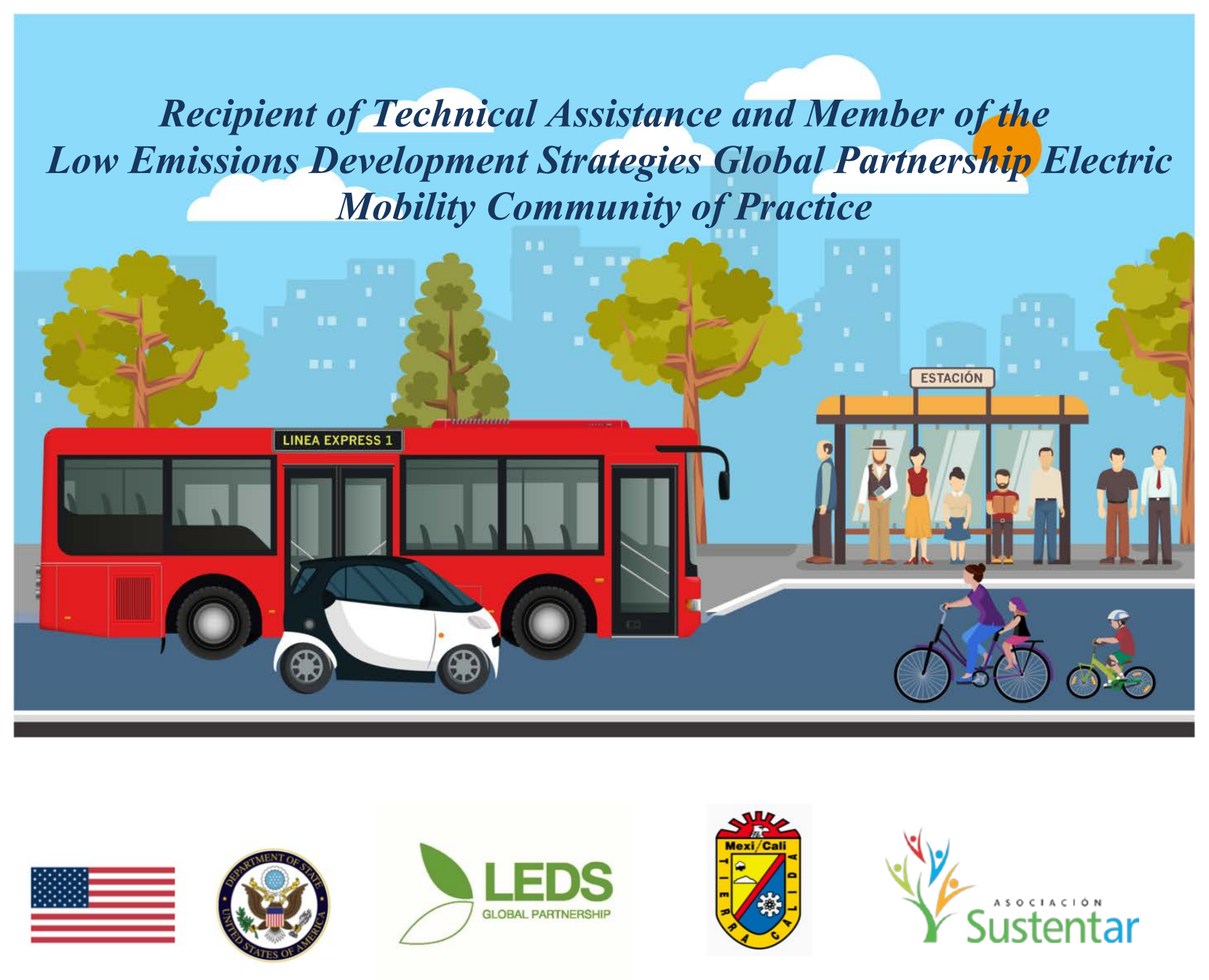




\title{
GNREL
}

\section{Foundations of an Electric Mobility Strategy for the City of Mexicali}

\author{
Caley Johnson, Sanjini Nanayakkara, Jeff Cappellucci, \\ and Matthew Moniot
}

National Renewable Energy Laboratory

\section{Suggested Citation}

Johnson, Caley, Sanjini Nanayakkara, Jeff Cappellucci, and Matthew Moniot. 2020.

Foundations of an Electric Mobility Strategy for the City of Mexicali. Golden, CO: National

Renewable Energy Laboratory. NREL/TP-5400-75690.

https://www.nrel.gov/docs/fy20osti/75690.pdf.

NREL is a National Laboratory of the U.S. Department of Energy

Office of Energy Efficiency \& Renewable Energy

Operated by the Alliance for Sustainable Energy, LLC

This report is available at no cost from the National Renewable Energy Laboratory (NREL) at www.nrel.gov/publications.

Contract No. DE-AC36-08GO28308
Technical Report

NREL/TP-5400-75690

May 2020

National Renewable Energy Laboratory 15013 Denver West Parkway Golden, CO 80401

303-275-3000 • www.nrel.gov 


\section{NOTICE}

This work was authored, in part, by the National Renewable Energy Laboratory, operated by Alliance for Sustainable Energy, LLC, for the U.S. Department of Energy (DOE) under Contract No. DE-AC3608GO28308. Funding provided by the United States Agency for International Development (USAID) under Contract No. IAG-17-2050. The views expressed herein do not necessarily represent the views of the DOE or the U.S. Government, or any agency thereof, including USAID.

This report is available at no cost from the National

Renewable Energy Laboratory (NREL) at

www.nrel.gov/publications.

U.S. Department of Energy (DOE) reports produced

after 1991 and a growing number of pre-1991

documents are available

free via www.OSTI.gov.

Cover Illustration by Laura Camila Cruz.

NREL prints on paper that contains recycled content. 


\section{Acknowledgments}

This report was developed and delivered to the City of Mexicali's Transport Team as a part of the Low Emissions Development Strategies (LEDS) Global Partnership Transport Working Group 2018 activities, in which select members were provided with technical assistance for a priority or challenge of their choice.

Mexicali is a member of the LEDS Latin America and Caribbean Electric Mobility Community of Practice, which was launched in March 2018. This Community of Practice forms a platformvirtual and in person - for transport sector stakeholders within the region to share experiences and peer learning and to receive technical guidance on planning and implementing sustainable transport actions. The Electric Mobility Community of Practice consists of over 50 members from across 10 countries, and members decided to focus on planning and implementation strategies for electric mobility in 2018 and 2019. The active engagement and participation of Mexicali's Transport Team was a critical component of the success of this project.

Funding for the technical work was provided by the United States Agency for International Development (USAID)-NREL Partnership's Technical Assistance Program. Additional coordination and planning activities were funded by the United States State Department through the Low Emissions Development Strategies Global Partnership Transport Working Group, a nocost open network that brings together practitioners working on low-emission development. To join, please visit www.ledsgp.org/join.

This roadmap would not have been possible without the shared insight and help from the following individuals:

Laura Cruz (Asociación Sustentar)

Mexicali Team: Adriana Macias, José Trinidad, Luis Alfonso Vizcarra, Arturo Sanchez, and Manuel Otanez

Claudia Vizcarra (Autonomous University of Baja California)

Alejandro Castillo (Grupo de Financiamiento Climático para Latinoamérica y el Caribe)

For more details regarding this report, contact the Low Emissions Development Strategies Global Partnership at www.ledsgp.org or transport@ledsgp.org. 


\section{Executive Summary}

The municipality of Mexicali, Mexico, has numerous energy, environmental, and transport goals and has made progress toward achieving them. Nonetheless, Mexicali still faces intertwined challenges such as high greenhouse gas (GHG) emissions, poor air quality, and increasing motorization rate and related traffic that hamper additional progress. This report seeks to support Mexicali in achieving these goals and overcoming challenges by describing technical pathways to transportation electrification and providing targeted analysis to inform Mexicali's electromobility strategy.

Twenty-eight percent of Mexicali's electricity generation mix is from renewable energy sources, so a transition to plug-in electric vehicles (PEVs) has the potential to reduce the mass of greenhouse gases (GHGs) per kilometer driven two-thirds below that of conventional vehicles. This GHG benefit grows as the share of renewables in Mexicali's electricity supply increases. Beyond increasing renewables, the strategic deployment of PEVs geographically (where feeders can handle additional load) and temporally (off peak between 9 p.m. and 11 a.m.) distributes additional load so that grid upgrades are minimized. A number of charge timing control mechanisms - at various stages of development - can support strategic deployment of PEVs in Mexicali.

Mexicali has a number of fleets that could make good early adopters of PEVs. Mexicali's taxi fleet is an early adopter of PEVs but their deployment has been plagued by performance issues related to high ambient temperatures. This report offers short and long-term strategies for extending taxi fleet range and prioritizes other types of fleets suitable for electrification based on key metrics. Once fleets have increased PEV acceptance and electric vehicle supply equipment (EVSE) installations, the market will be ready to expand to private vehicle owners. EVSE installed in the right location is essential. A combination of traffic patterns, land use, and demographic data indicate that Mexicali has many areas throughout the city that have strong potential for public EVSE installation.

This report seeks to formulate a custom-designed, practical, and data-driven framework to enable Mexicali to transition their transport sector to cleaner electric mobility. It provides a brief overview of the benefits of electric vehicles (Section 2) followed by considerations for electricity grid preparation and management (Section 3) so that the benefits of electromobility can be maximized and grid impacts minimized. Section 4 discusses how Mexicali can utilize vehicle fleets as early adopters of PEV technology, including ways to prioritize fleets for electrification, incentivize fleets to purchase PEVs, and understand how transport electrification can facilitate mass transit. This section also evaluates Mexicali's taxi fleet — an early adopter of PEVs — and presents strategies for overcoming early performance challenges. Section 5 discusses how to expand the individual PEV market through deployment of EVSE and other incentives. Lastly, Section 6 discusses the importance of capacity building and training of PEV repair technicians, EVSE installation electricians, and first responders, so that PEVs and related infrastructure remain safe, effective, and reliable. 


\section{List of Acronyms}

CFE Comision Federal de Electricidad

EV electric vehicle

EVSE electric vehicle supply equipment

GHG greenhouse gas

HEV hybrid electric vehicle

KI kinetic intensity

MCDA multi-criteria decision analysis

NREL National Renewable Energy Laboratory

PEV plug-in electric vehicle

PHEV plug-in hybrid electric vehicle

USAID United States Agency for International Development 


\section{Table of Contents}

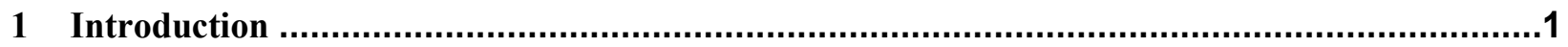

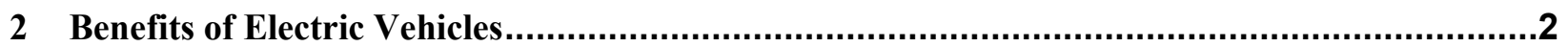

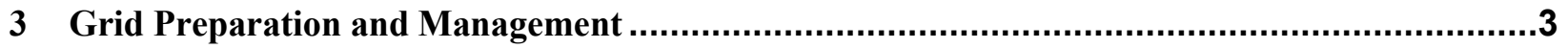

3.1 Increase the Share of Renewables into the Power Generation Mix to Increase the Benefits of EVs .............................................................................................................. 3

3.2 Spatial Grid Preparation ............................................................................................. 5

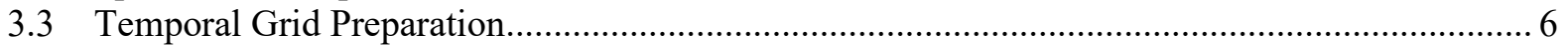

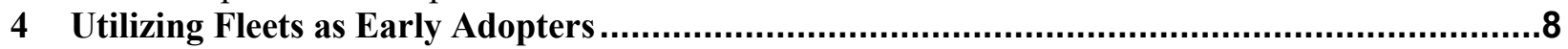

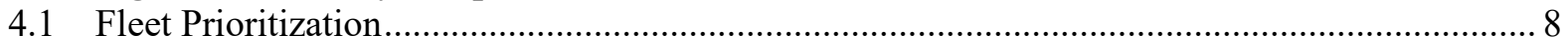

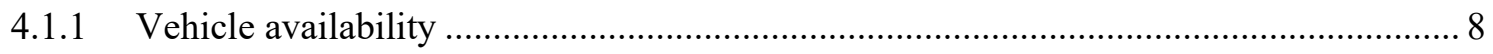

4.1.2 Vehicle routes that are compatible with charging needs ............................................. 10

4.1.3 Vehicles that brake and accelerate often .................................................................... 10

4.1.4 Vehicles that perform jobs while idling .................................................................... 10

4.1.5 Vehicle owners that value PEV co-benefits such as noise and emissions reduction ...... 11

4.1.6 Fleet vehicles with high annual GHG emissions......................................................... 11

4.1.7 Fleet compatibility with electric grid …………………………………………... 12

4.1.8 Summary of fleet prioritization ......................................................................... 12

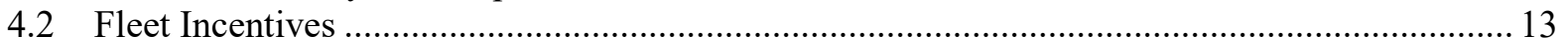

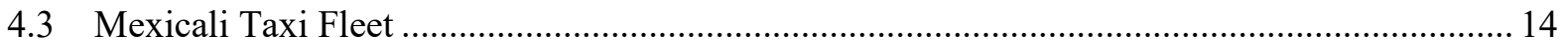

4.4 Electric Mobility and Mass Transit ........................................................................................ 17

5 Expansion to Individual Driver PEV Market ..............................................................18

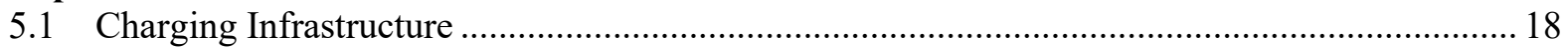

5.2 Charging Station Location Analysis................................................................................... 21

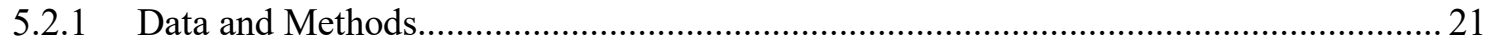

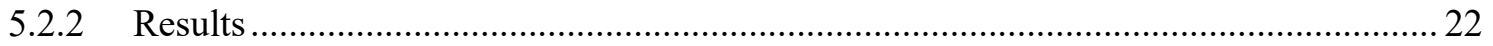

5.2.3 Limitations \& Areas for Improvement................................................................... 23

5.2.4 Geospatial Analysis Conclusion.........................................................................2 24

5.3 PEV Purchase Incentives .............................................................................................. 24

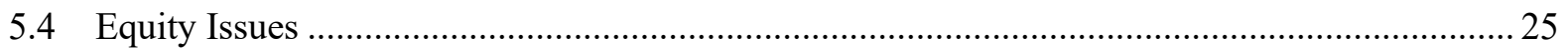

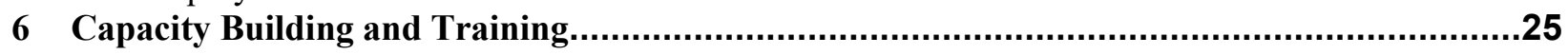

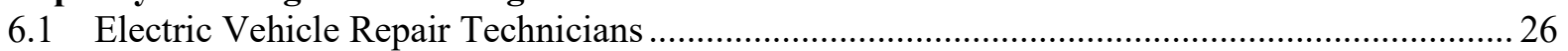

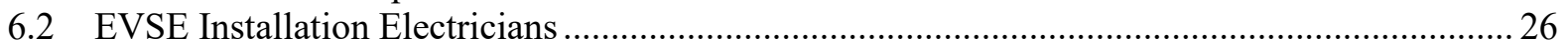

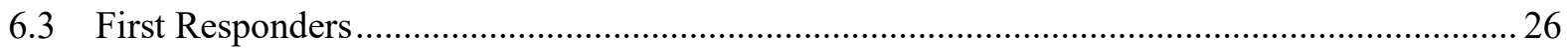

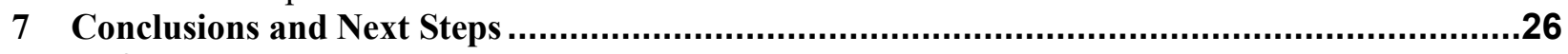

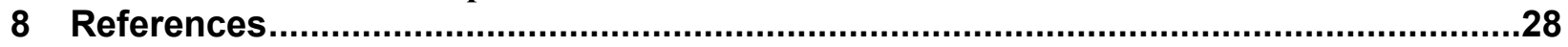




\section{List of Figures}

Figure 1. Electric generation capacity by source in the Mexicali region, 2018 ....................................... 4

Figure 2. GHG emissions from PEVs and their conventional counterparts on Mexicali's electrical grid as renewables are added

\section{5}

Figure 3. Percent loading and available capacity at all feeders in Seattle (x-axis represents unique feeder IDs)

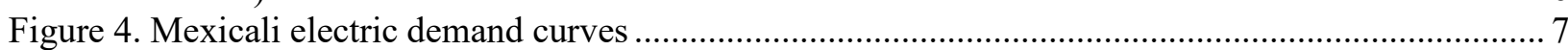

Figure 5. Fleet DNA's daily average driving speed and KI by vehicle type ....................................... 10

Figure 6. Annual petroleum use of various vehicle types in the United States (Gasoline Liter Equivalents represent both diesel and gasoline)....

Figure 7. Real-world taxi performance generated and collected under this project from a Nissan Leaf in

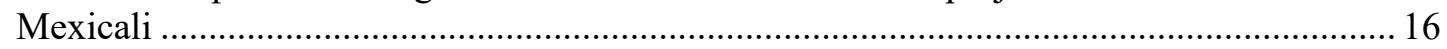

Figure 8. Heat map of electric taxi in Mexicali using data collected under this project.......................... 17

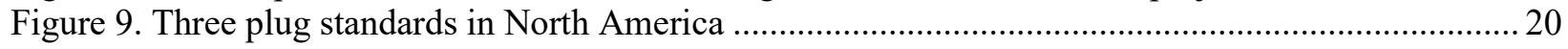

Figure 10. Mexicali potential public EVSE infrastructure ..................................................................... 22

\section{List of Tables}

Table 1. PEV Charge Timing Control Mechanisms .............................................................................. 8

Table 2. Transit Bus Manufacturers That Sell to the North American or Latin American Markets............. 9

Table 3. Fleets That Are Most Compatible with PEVs, by Fleet Attribute …......................................... 13

Table 4. Overview of the EVSE Standards Used in Various Regions................................................... 19

Table 5. Efficacy of Electric Vehicle Purchase Incentives in the United States...................................... 25 


\section{Introduction}

According to the World Economic Forum, worldwide rapid urbanization is predicted to increase the global population living in cities up to $68 \%$ by 2050 , raising pressure on infrastructure and challenging mobility and transportation services (ITF 2015). As such, the Municipality of Mexicali, located in the State of Baja California, Mexico, has recently experienced a rapid rate of urbanization that has resulted in several challenges, namely high greenhouse gas (GHG) emissions, poor air quality, and increasing motorization rate and related traffic. This report provides approaches, considerations, and best practices to address these challenges and inform Mexicali's transition to cleaner, electric transport sector in a way that aligns with Mexico's national and subnational priorities.

Recently, Mexico's national government has made progress on implementing the National Strategy on Climate Change (SEMARNAT-INECC 2016), which includes a vision for the transport sector: to increase sustainable modes of transportation and transition to public and private electric transport. The Sixth National Communication on Climate Change for Mexico (UNDP 2015) shows that emissions from the transport sector account for $24 \%$ of the national total and these emissions have experienced an annual average growth rate of 3.2\%. The road transport subsector generates $93.3 \%$ of the emissions in this sector. In its National Climate Change Strategy (Gobierno de la República 2013), Mexico established actions to reduce GHG emissions in the transport sector, focusing on: 1) replacing fossil fuels in the transport sector, 2) implementing a National Electric Mobility Policy, and 3) establishing urban public transport corridors. Additionally, the government of Mexico developed a National Air Quality Strategy in 2017, which is implemented at the subnational level through Programs to Improve Air Quality (Spanish acronym PROAIRE). The National Air Quality Strategy establishes sustainable guidelines in transport and mobility planning processes. It requires all states to establish short-, medium-, and long-term actions to reduce air pollutants based on the size and age of the fleet. The National Electric Mobility Strategy was established in 2018 to reinforce guidelines on technical, financial, legal, institutional, and administrative requirements and priorities for the transport sector. It also introduced incentives to promote and position electric mobility as a viable and sustainable alternative for mobility at the national level.

At the subnational level, the Municipality of Mexicali has made significant efforts to implement Mexico's nationally determined contribution under the United Nations Framework Convention on Climate Change (UNFCCC) Paris Agreement and to implement the National Air Quality Strategy at the municipal and state levels through the following actions:

1. Formulating a Baja California Program on Climate Change in 2015, in addition to an air quality strategy (PROAIRE of Baja California 2018-2027 and PROAIRE of Mexicali 2011-2020). This program included actions to reorganize transport routes, renew fleets, and develop a planning instrument to improve energy efficiency.

2. Analyzing the implementation potential and the costs of low-carbon technologies for the public-transport sector in the metropolitan area of Mexicali with the support of the National Institute of Ecology and Climate Change (INECC by its acronym in Spanish) (SEMARNAT-INECC 2016). 
3. Establishing an agreement of immediate-, short-, and medium-term actions with public transport companies to implement improvements and to annually renew $10 \%$ of the total fleet, creating the opportunity to incorporate electric vehicles (EVs).

4. Establishing an agreement with the Autonomous University of Baja California to receive support from engineering faculty students for the development of key areas of the Foundations of the Electric Mobility Strategy that require additional work.

5. Actively engaging a strategy for the "right to a healthy environment" in the framework of the Mexico-United States Environmental Border Program 2012-2022.

Despite these efforts, barriers still limit the transition to sustainable mobility. These include the advanced age of the public and private transport fleets, limited data (to generate strategies and regulatory frameworks necessary to encourage the introduction of zero-emission technologies in the transport sector), and limited understanding of how the power needs of large fleets of EVs may affect the grid. NREL provided technical assistance at the request of Mexicali's Transport Team in the LEDS Latin America and Caribbean Electric Mobility Community of Practice to help address these barriers and support Mexicali in achieving their electromobility goals.

This report seeks to formulate a custom-designed, practical, and data-driven framework to enable Mexicali to transition their transport sector to cleaner electric mobility. It provides a brief overview of the benefits of electric vehicles (Section 2) followed by considerations for electricity grid preparation and management (Section 3 ) so that the benefits of electromobility can be maximized and grid impacts minimized. Section 4 discusses how Mexicali can utilize vehicle fleets as early adopters of PEV technology, including ways to prioritize fleets for electrification, incentivize fleets to purchase PEVs, and understand how transport electrification can facilitate mass transit. This section also evaluates Mexicali's taxi fleet - an early adopter of PEVs - and presents strategies for overcoming early performance challenges. Section 5 discusses how to expand the individual PEV market through deployment of EVSE and other incentives. Lastly, Section 6 discusses the importance of capacity building and training of PEV repair technicians, EVSE installation electricians, and first responders, so that PEVs and related infrastructure remain safe, effective, and reliable.

\section{Benefits of Electric Vehicles}

Electric vehicles hold numerous advantages over conventional vehicles. They are approximately 3.3 times more efficient (U.S. DOE EERE 2019a), allowing many more transport functions to be performed for a given amount of energy. This efficiency improvement is partially due to improved motor efficiency and regenerative braking, whereby kinetic energy can be converted into electric energy rather than into waste heat in the brake pads. Electric vehicles also generally reduce GHG emissions due to increasing levels of low-carbon electricity in grids worldwide. Plug-in electric vehicles (PEVs) can also lead to improved health of a population by reducing harmful air pollutants from urban areas. They do this by decoupling energy from emissions; electricity can be generated a significant distance away from sensitive populations and large scrubbers can be used to minimize emissions. Then the electricity is transported to the point of use (usually in densely populated urban areas) where the PEV emits no ozone-forming pollutants or carbon monoxide, only particulate matter from tire wear, break wear, and dust (Timmers and Achten 2016). 
EVs also provide performance benefits. They provide superior low-end torque that translates to strong and consistent acceleration from a stop. This is especially noticeable when going uphill. PEVs are also quieter during most city driving conditions since they have fewer moving parts and no moving parts during idling (Iversen 2015), reducing noise pollution. Finally, PEVs have the potential to facilitate mass transit, thereby reducing traffic and improving safety. This benefit is discussed at greater length in Section 4: Electric Mobility and Mass Transit.

\section{Grid Preparation and Management}

Power sector decision makers must prepare for and manage electromobility in order to fully realize its GHG benefits and to minimize potential grid impacts. Mexicali's grid needs additional preparation in order to fully realize the benefits of electromobility. First, the grid must continue to absorb increasing levels of renewable energy, coupled with energy efficiency improvements, so that PEVs emit the fewest GHGs possible. Second, grid operators must prepare the grid to handle the increasing numbers of PEVs in a way that would not disrupt regular service. This can be done both geographically (across the city) and temporally (across hours of the day and months of the year). Grid preparation can be done in concert with the early stages of market development discussed in subsequent chapters of this report. Given the current power sector in Mexico, Mexicali itself may have limited ability to influence these activities and would need to work with Comisión Federal de Electricidad (CFE)-Mexico's state-owned utility to adequately prepare for electromobility.

\subsection{Increase the Share of Renewables into the Power Generation Mix to Increase the Benefits of EVs}

Twenty-eight percent of Mexicali's electricity comes from renewable energy (including geothermal, solar, and waste to energy), as shown in Figure 1. With this grid mix, PEVs already emit far fewer GHG emissions than conventional vehicles, but this can be improved upon. There are additional subnational or national policies that Mexicali or Mexico could consider to incentivize additional renewable energy penetration on the grid, however, a comprehenisve overview is beyond the scope of this report ${ }^{1}$.

\footnotetext{
${ }^{1}$ For more information on enabling policy and operational practices for renewable energy integration, please see these resources: https://greeningthegrid.org, https://cleanenergysolutions.org, www.dsireusa.org.
} 


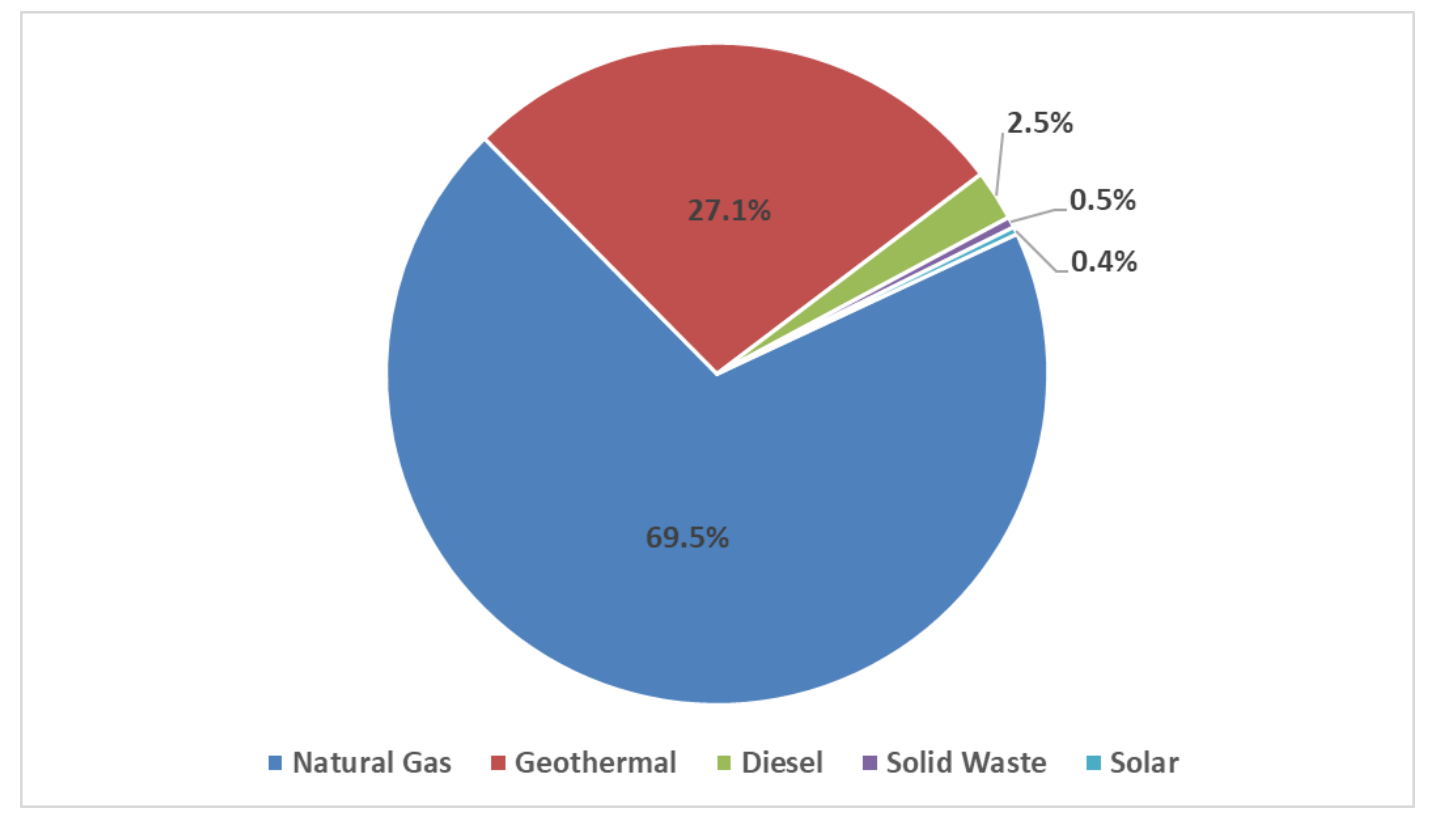

Figure 1. Electric generation capacity by source in the Mexicali region, 2018

Source: City of Mexicali, 2019a

NREL used the PEV Benefits by Electricity Source Model $^{2}$ to estimate the relative GHG benefits of PEVs and other vehicles, based on the Mexicali fuel mix, now and into the future as the share of renewable electricity increases. A few model inputs were not available for Mexicali, so U.S.based default assumptions were used. These include transportation fuel emissions factors and energy contents (from Wang et al. 2018) and electricity generation emissions factors (from U.S. Environmental Protection Agency 2018). EVSE efficiency is assumed to be $99 \%$, based on Level 2 chargers as reported by Energy Star (2013). Electricity generation from diesel is assumed to be $25 \%$ efficient and conversion efficiency from natural gas is assumed to be $45 \%$, based on U.S. EIA (2018). All vehicle fuel consumption rates come from www.fueleconomy.gov, which assumes that vehicles are driven 55\% on the U.S. City Drive Cycle and $45 \%$ on the U.S. Highway Drive Cycle.

Figure 2 shows the relationship between the percentage of renewable energy and the magnitude of GHG benefits in using PEVs, as modeled by the PEV Benefits by Electricity Source Model. Emissions from PEVs in Mexicali could decrease further if the percentage of renewables in the electricity mix increases. The model uses one popular vehicle in a variety of vehicle classes for illustrative purposes. The starting point of 28\% renewables (per $2018 \mathrm{mix}$ ) shows that the Nissan Leaf emits one-third the GHGs of its gasoline-powered counterpart, the Nissan Versa. The Chevy Volt, a plug-in hybrid electric vehicle (PHEV), emits about half the GHGs of a Versa. ${ }^{3}$ The Toyota Prius hybrid electric vehicle (HEV) can yield a substantial reduction in GHGs from the comparably sized Versa regardless of Mexicali's electric generation mix. As renewable energy increases,

\footnotetext{
${ }^{2}$ The PEV Benefits by Electricity Source Model is internal and proprietary at this time. Please contact authors for more information.

${ }^{3}$ This number depends on length of average trip, but was found to be $55 \%$ in a study in the United States (Smart, Bradley, and Salisbury 2014) and assumed to be the same in Mexicali.
} 
emissions from the Highlander (sport utility vehicle included to show the benefits of downsizing), Versa, and Prius are not impacted because they use no electricity. When Mexicali reaches Mexico's 2050 goal of increasing the use of renewable energy sources to 50\% (SENER 2016), a Leaf will emit 78\% fewer GHG emissions than the Versa and less than half the amount of the Volt. These results indicate that under current conditions, EVs reduce GHG emissions substantially compared to their gasoline-powered counterparts, and emissions further decline as the grid becomes greener

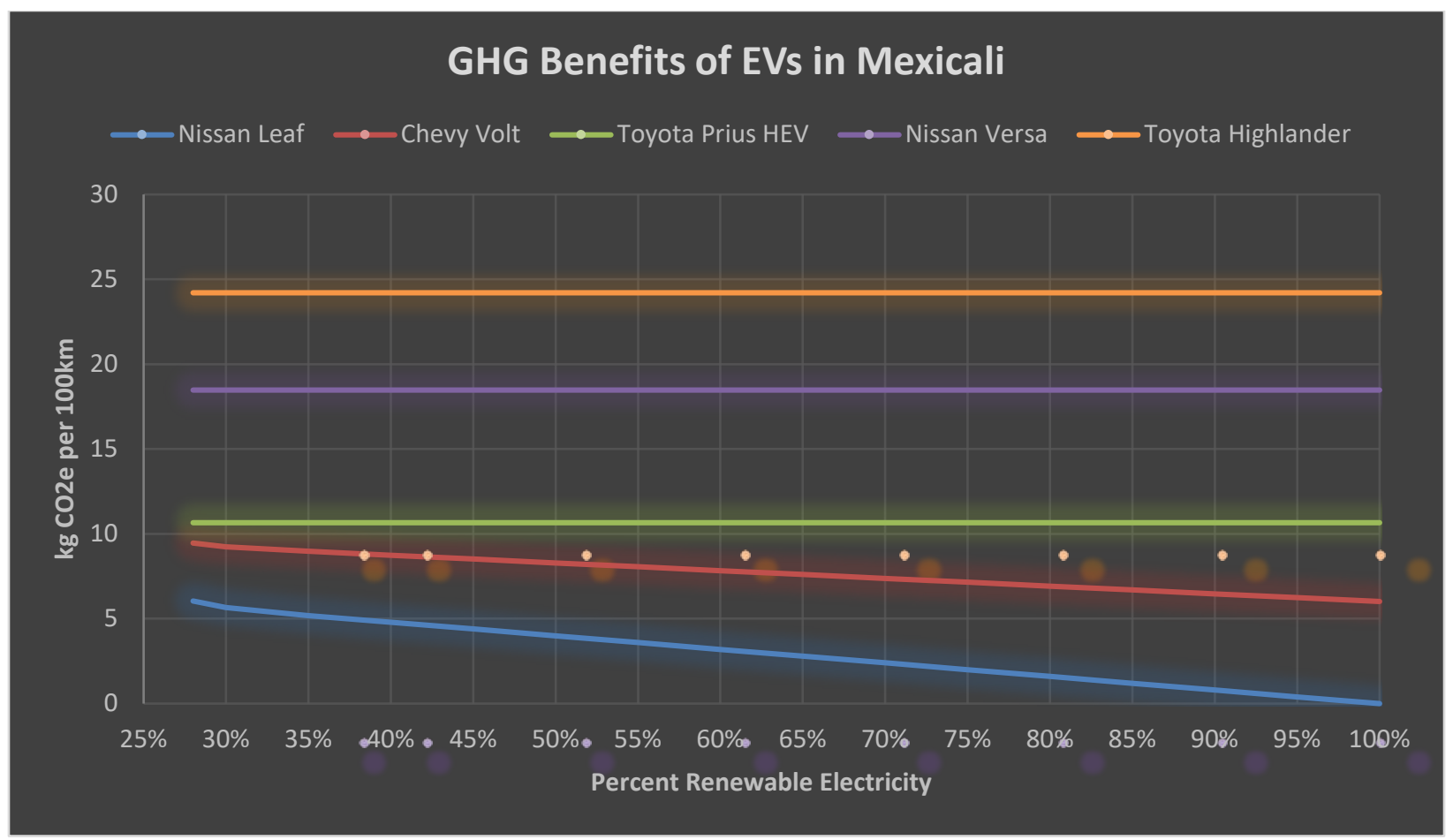

Figure 2. GHG emissions from PEVs and their conventional counterparts on Mexicali's electrical grid as renewables are added

\subsection{Spatial Grid Preparation}

At low levels of PEV deployment, electric grid impacts may be minimal, but increased deployment of these vehicles can substantially increase electric load in certain regions of the grid and may require strategies to manage these impacts. Overall, the increased electric load from substantial conversion to electromobility may be manageable for most developing countries if done properly (Grütter and Kim 2019). A distribution feeder-level analysis of the grid, similar to the one done by Seattle City Light (Daniels and O’Donnell 2019), is one way a utility could ensure grid compatibility when faced with significant levels of PEV deployment. Distribution feeders are a portion of the city grid that lies downstream of transformers that reduce voltage to levels compatible with the area's appliances. In their analysis, Seattle City Light assessed the load of each of its feeders in comparison to its capacity. This informed them of the available capacity each feeder had that could be used to charge additional PEVs (Figure 3). 

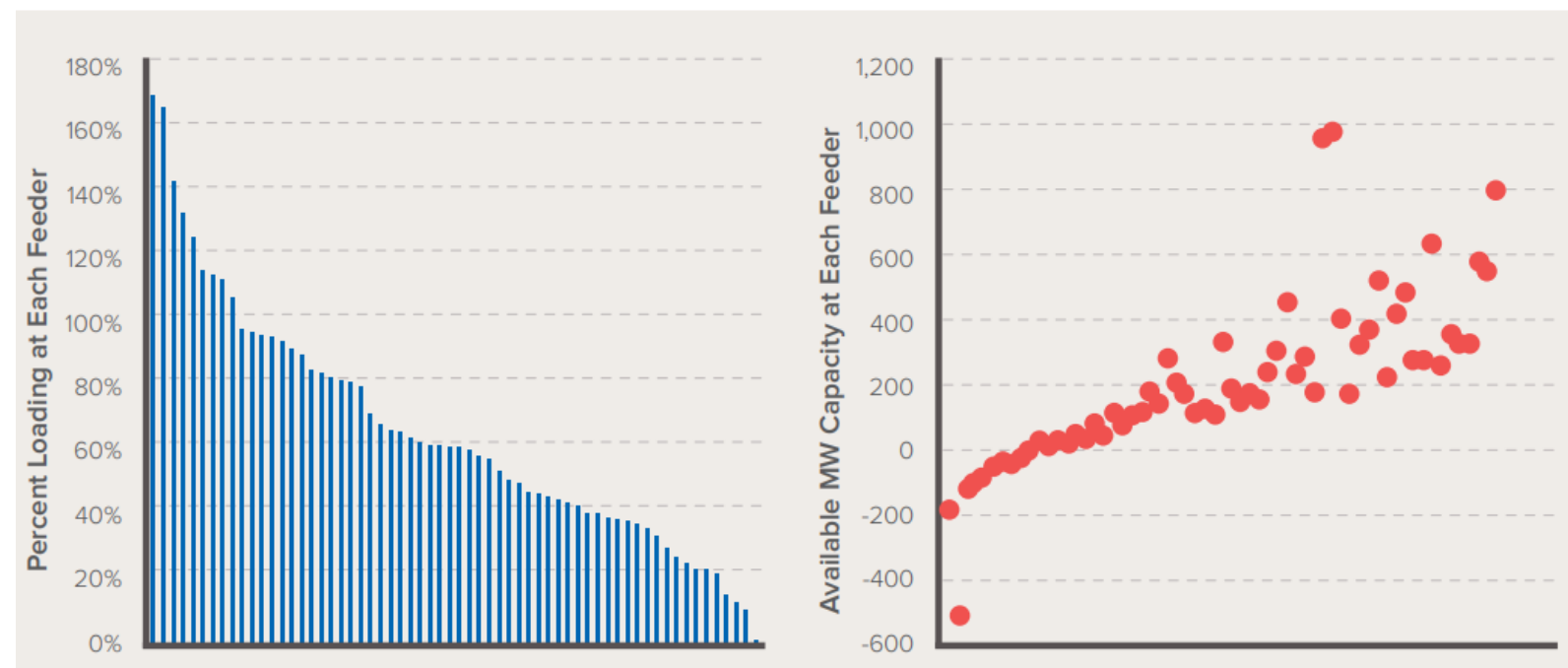

Figure 3. Percent loading and available capacity at all feeders in Seattle (x-axis represents unique feeder IDs)

Source: Daniels and O’Donnell 2019

A feeder demand analysis of the distribution system in Mexicali would inform two key strategies decision makers in Mexicali could take (in partnership with CFE as needed): 1) they could target fleets and demographics on underutilized feeders for electrification, which will be discussed in Section 5 below, or 2 ) they could increase the capacity of feeders that are likely to be over capacity when a given vehicle electrification rate is achieved. Increasing capacity is the more expensive option. For example, Seattle City Light cites that "at $4 \mathrm{MW}$ for a single installation, there may be need to reconductor a lateral with an estimated cost of $\$ 1,000 /$ foot of overhead installation or $\$ 1,500 /$ foot for underground installation. However, for fleets on the higher end of the range (above $10 \mathrm{MW}$ ), system impact studies will be required as this size load may require a dedicated feeder." (Daniels and O'Donnell 2019). To determine how much power a fleet will demand, planners should focus on the electric vehicle supply equipment (EVSE) instead of the vehicles since the EVSE sets the top rate at which vehicles fill.

\subsection{Temporal Grid Preparation}

Another strategy that reduces strain on the grid is the management of vehicle charge timing. Every grid goes through "peak load" - a point or two in the day when it is distributing its maximum quantity of kilowatts because consumers are using the most electricity. Increasing demand during peak load is very expensive for the utility to serve because it requires them to increase generation capacity. Conversely, adding demand during low-load times (i.e. "off-peak") is usually inexpensive because existing capacity can be used to produce all necessary electricity. Figure 4 shows that off-peak times in Mexicali are all day during the winter and from 9 p.m. to 11 a.m. during the summer. 


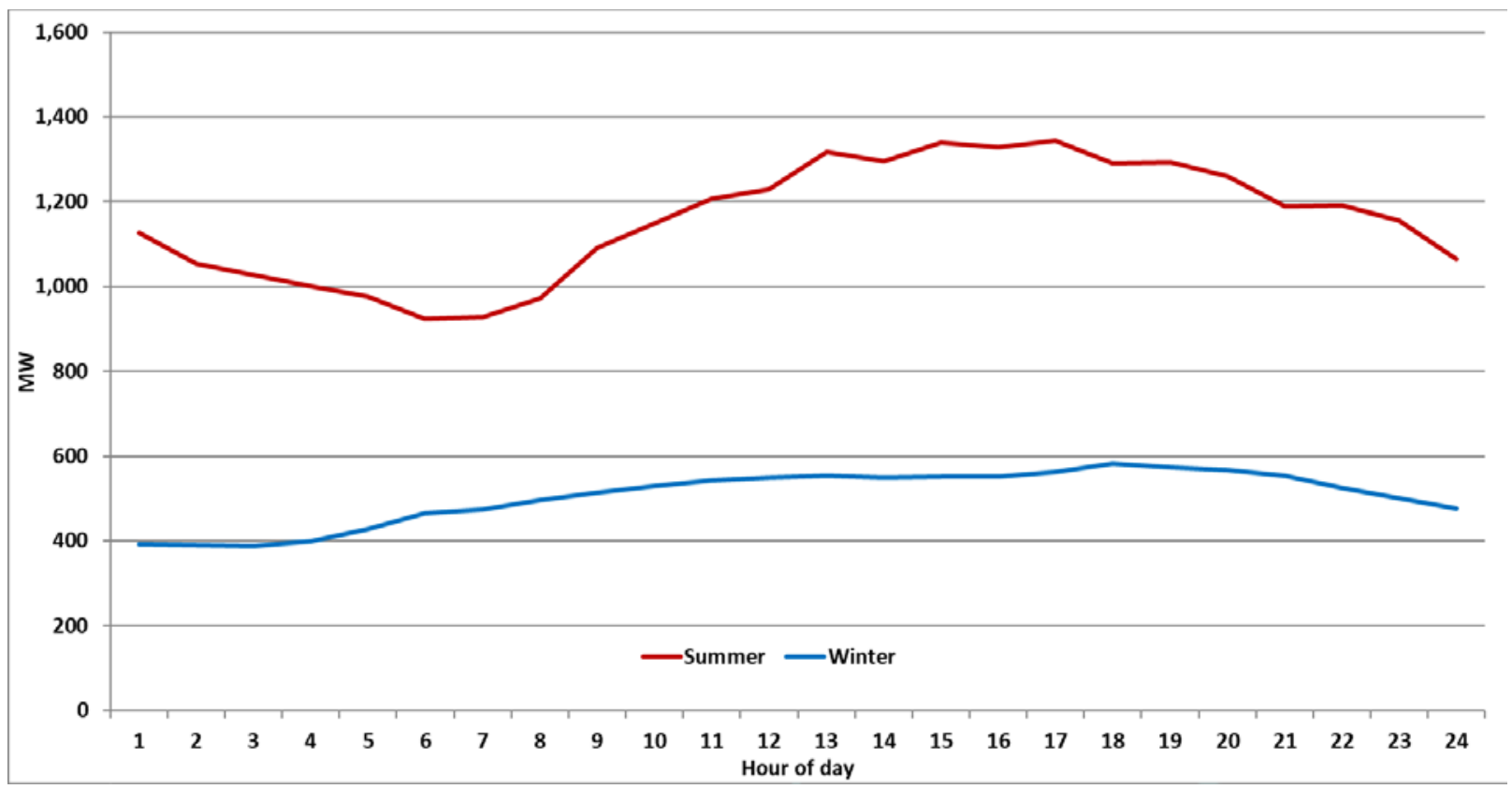

Figure 4. Mexicali electric demand curves

Data Source: Source: City of Mexicali, 2019a

A best practice for Mexico's power sector stakeholders (in this case, the regulator, Comisión Reguladora de Energía [CRE] and CFE) to consider would be to implement a mechanism that encourages PEVs to charge during low-load times (between 9 p.m. to 11 a.m.). Table 1 summarizes some of the other options discussed in Hodge (2017) that can be used as the equipment becomes available and the need increases due to increased PEV penetration. The first clusters of PEVs are often fleet vehicles, which have the advantage of regular schedules and professional drivers. This group is well suited to utilize one of the currently available "PEV interfaces" to successfully steer their charging to off-peak times. The PEV interface is essentially a timer built into the PEV or EVSE that delays charging until a certain time. As the PEV deployment expands to individuals for commuting purposes, EVSE network controls could become more necessary. This mechanism not only helps to shift load to off-peak times, but it can also help shift load away from specific areas of the grid that are at risk of overloading their capacity towards areas that can take additional load. At the time of publication, at least 23 EVSE networks in the United States had timing control capabilities and that number is rising rapidly (Myers 2019).

Charge timing can also be controlled through integrated facility energy management systems. Such systems allow facility operators to level their demand by coordinating interruptible electric loads such as air conditioners and EVSEs. One way for a utility to motivate electric load management regardless of the management technology is through price signals. Time-of-use pricing, where a given amount of electricity costs different amounts depending on the time of day, week, or season, is a price signal that is relatively easy to implement (Eid et al. 2016). Real-time pricing, where the price of electricity adjusts automatically to reflect supply and demand at any given moment, typically requires additional equipment but can better match PEV demand with electricity generated by renewable sources (e.g. Mexicali's planned wind and solar projects). Although realtime pricing leaves decisions up to the EV owner, there is an increasing array of technologies that 
better automate the link between pricing and PEV charge timing, which are currently being piloted by numerous U.S. utilities (Myers 2019).

Table 1. PEV Charge Timing Control Mechanisms

\begin{tabular}{|c|c|c|c|c|}
\hline & PEV Interface & EVSE Network & $\begin{array}{l}\text { Facility Energy } \\
\text { Management }\end{array}$ & Price Signals \\
\hline Administrator & $\begin{array}{l}\text { Consumer, fleet } \\
\text { manager }\end{array}$ & $\begin{array}{l}\text { Consumer, fleet } \\
\text { manager, facility } \\
\text { manager, utility }\end{array}$ & Facility manager & $\begin{array}{l}\text { Utility, facility } \\
\text { manager }\end{array}$ \\
\hline Application & $\begin{array}{l}\text { Control individual } \\
\text { vehicle }\end{array}$ & $\begin{array}{l}\text { Control individual or } \\
\text { multiple vehicles }\end{array}$ & $\begin{array}{l}\text { Control building } \\
\text { and vehicles }\end{array}$ & $\begin{array}{l}\text { Influencing charging } \\
\text { using electricity price }\end{array}$ \\
\hline Benefits & No cost, simple & $\begin{array}{l}\text { Programmable for } \\
\text { multiple vehicles, } \\
\text { simple, flexible }\end{array}$ & $\begin{array}{l}\text { Improved facility } \\
\text { load control }\end{array}$ & $\begin{array}{l}\text { Aggregated at utility } \\
\text { level, relies on } \\
\text { downstream controls }\end{array}$ \\
\hline Drawbacks & $\begin{array}{l}\text { Does not offer } \\
\text { aggregation }\end{array}$ & $\begin{array}{l}\text { No facility } \\
\text { integration, not } \\
\text { standardized across } \\
\text { brands, added cost }\end{array}$ & $\begin{array}{l}\text { Distance of control } \\
\text { from users, } \\
\text { administrative costs }\end{array}$ & $\begin{array}{l}\text { Potential rebound } \\
\text { peaks or complex } \\
\text { price signals and } \\
\text { automated controls, } \\
\text { communication }\end{array}$ \\
\hline
\end{tabular}

Source: Hodge 2017

\section{Utilizing Fleets as Early Adopters}

Fleets are often early adopters of new vehicle technologies such as PEVs because they have centralized decision makers, technicians, professional drivers, and tend to take life-cycle costs into consideration. Furthermore, they can lay the groundwork for adoption by the general public by serving as early PEV exposure and installing EVSE that can also be used by the general public. Both of these services lead to increased public adoption of PEVs (Singer 2019, Narassimhan and Johnson 2018).

\subsection{Fleet Prioritization}

Some fleets are more suitable for PEVs than others and therefore more likely to successfully electrify. These fleets need to be identified and targeted as potential early adopters. This section explains seven fleet parameters that could help Mexicali determine which fleets would be good candidates as early adopters of PEVs. It then ranks 10 fleets according to how favorable they are in each parameter.

\subsubsection{Vehicle availability}

The most basic determinant of a fleet's compatibility with electrification is if an electric version of their vehicles is manufactured.

Light-duty vehicles are the most widely available PEVs. In 2018, global stock exceeded 5.1 million of them - an increase of 65\% from the previous year (IEA 2019). At least 16 models are 
available in Mexico (Netherlands Enterprise Agency 2019), and Mexicali can probably access most of the 46 PEV models (new and used) that are available for sale in the United States (U.S. DOE EERE 2018b). Light-duty vehicles fill many important roles in various fleets. These vehicles can be compared by their attributes (including efficiency, range, cabin space, acceleration, and towing capacity) at www.fueleconomy.gov.

Low-speed electric vehicles are built to have a top speed of $40 \mathrm{~km} /$ hour but some U.S. states allow them to be driven on roads with speed limits of up to $72 \mathrm{~km} /$ hour (Hughes 2018). Low-speed electric vehicles are generally less expensive because they do not have to meet high-speed crash safety requirements that add much cost to vehicles. Furthermore, they tend to have less expensive batteries because they are lighter (easier to propel) and have shorter ranges. Low-speed electric vehicles are commonly used in fleets that shuttle people or goods between multiple buildings on a campus, like those at universities, retirement communities, resorts, golf clubs, and large corporations. They can accept J1772 plugs (the standard discussed in Section 6.1), and therefore EVSE installed for these vehicles can support full speed EVs as well.

Medium- and heavy-duty vehicles include buses and trucks of various sizes, and this market segment is relatively new for PEV technologies. The transit bus market has the most suppliers and the most vehicles in operation of any of the heavy-duty vehicle market (IEA 2019). Table 2 lists the electric transit bus manufacturers that sell to North America or Latin America. It is not certain if each of these companies sell their products in Mexico, but it is likely since they sell to Mexico's neighbors. Likewise, there are four companies that sell electric school buses in the United StatesBlue Bird, GreenPower, Lion, and Thomas Built (U.S. DOE EERE 2019b). Medium- and heavyduty electric trucks are still largely limited to retrofits (by companies such as Zenith Motors and Hybrid), but at least 12 companies (including Cummins, Daimler, Tesla, Volvo, and VW) have announced plans to introduce dedicated electric trucks between 2018 and 2022 (IEA 2019). Most that have been introduced to date are medium-freight trucks, with a fewer number of heavy-freight trucks.

Table 2. Transit Bus Manufacturers That Sell to the North American or Latin American Markets

\begin{tabular}{|l|l|l|}
\hline Manufacturer & Location & Website \\
\hline BYD & China & http://en.byd.com/usa/bus/ \\
\hline Changan & China & $\underline{\text { www.changanbus.com/en/ }}$ \\
\hline Ebus & U.S. & $\underline{\text { www.ebus.com/ }}$ \\
\hline Gillig & U.S. & $\underline{\text { www.gillig.com/ }}$ \\
\hline GreenPower & U.S. & $\underline{\text { www.greenpowerbus.com/ }}$ \\
\hline New Flyer & Canada & $\underline{\text { www.newflyer.com }}$ \\
\hline Novabus & U.S. & $\underline{\text { http://novabus.com/bus/lfse/ }}$ \\
\hline Proterra & U.S. & $\underline{\text { www.proterra.com/ }}$ \\
\hline VDL & Europe & $\underline{\text { https://www.vdlbuscoach.com/en }}$ \\
\hline Volvo & Europe & $\underline{\text { www.volvobuses.com/en-en/our-offering/electromobility.html }}$ \\
\hline Yutong & China & $\underline{\text { https://en.yutong.com/ }}$ \\
\hline
\end{tabular}

Data Sources: U.S. DOE EERE 2019b, IEA 2019 


\subsubsection{Vehicle routes that are compatible with charging needs}

Batteries are the most expensive component of PEVs, and their size and price increase commensurately with range. Therefore, the most compatible routes tend to be ones that regularly pass EVSEs (usually because they are repetitive) and offer time to charge during the day. Transit buses, school buses, campus vehicles, commuters, and some delivery trucks exhibit this attribute.

\subsubsection{Vehicles that brake and accelerate often}

Drive cycles that brake and accelerate often greatly increase energy use in conventional vehicles, but not as much in PEVs largely because PEVs can capture their kinetic energy through regenerative braking and then use it to accelerate. This measure of how much a vehicle stops and accelerates is known as kinetic intensity $(\mathrm{KI})$. Drive cycles with a high KI stand to benefit more from PEVs than drive cycles with a low KI. The National Renewable Energy Laboratory's (NREL's) Fleet DNA database (NREL 2019) has the KI of 486 vehicles, driven over 4,700 days, that are searchable by vocation, vehicle type, and other attributes. It is not known how precisely these attributes apply to Mexicali fleets, but within the United States a vehicle's KI is much more strongly related to their vocation than their location. Figure 5 displays the KI of 14 vehicle types. Of these 14, walk-in (delivery trucks), transit buses, dump trucks, and school buses have the highest average and median KI.

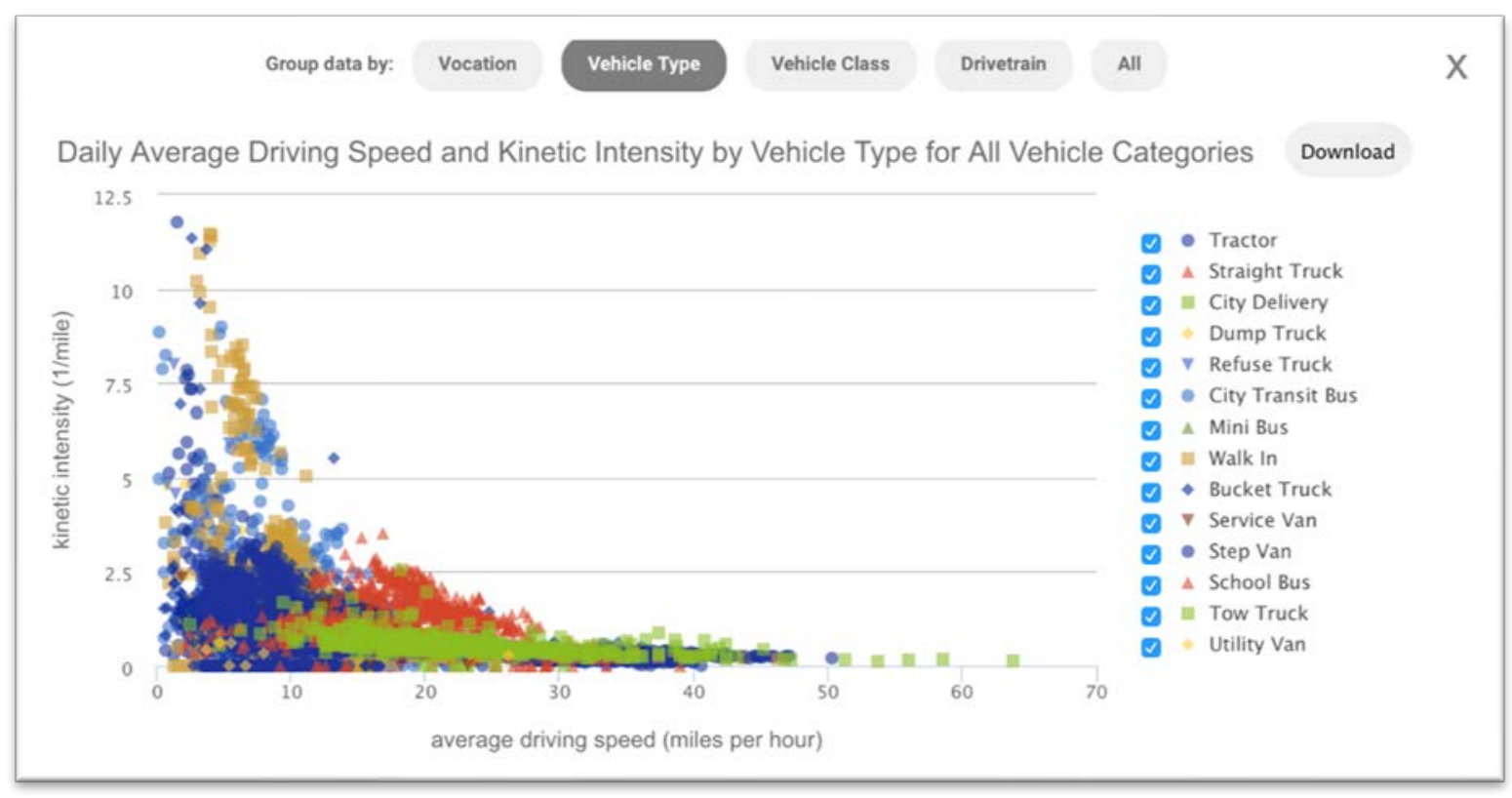

Figure 5. Fleet DNA's daily average driving speed and KI by vehicle type

Source: NREL 2019

\subsubsection{Vehicles that perform jobs while idling}

Many vehicles need to power equipment such as hydraulics, compressors, air conditioners, or heaters while idling. When powering such ancillary loads, the engine is operating far outside its optimal load and therefore operates very inefficiently. Electric motors have a much wider range of optimal load and therefore can power such ancillary uses with much less energy use. Utility trucks, refuse trucks, cement mixers, refrigerated trucks, and air-conditioned buses can most benefit from 
EVs' idle-reducing capabilities. However, as the taxi fleet has shown Mexicali (as elaborated in section 4.3), caution must be taken when it comes to air-conditioning loads in Mexicali. Temperatures in the city tend to be higher than most vehicle manufacturers design for, so air conditioning loads can reduce range substantially.

\subsubsection{Vehicle owners that value PEV co-benefits such as noise and emissions reduction}

The quiet operation of PEVs is likely to be most valued on resorts and campuses. The small size, pedestrian-friendly attributes, and open-air configurations of low-speed electric vehicles are also particularly valuable in these settings. The lack of tailpipe emissions is particularly valuable for populations more vulnerable to their detrimental health effects (e.g. the young, elderly, or sick). This means that school buses, shuttle buses, and campus vehicles on schools, hospitals, and retirement communities could be good early fleets to consider for electrification. Using PEVs in urban centers maximizes their impact on air-quality related health benefits since these areas have the highest density of people breathing the air. Transit buses are particularly deployed to city centers and other settings with dense populations.

\subsubsection{Fleet vehicles with high annual GHG emissions}

These vehicles allow for greater emissions reductions when replaced by electric vehicles. The well-to-wheel GHG emissions of petroleum vehicles reflect their annual fuel use, which is generally a function of fuel economy and distance driven per year, with fuel use increasing commensurately with distance traveled per year and decreasing with fuel economy. Figure 6 shows the annual fuel use of various fleet vehicles in the United States. This takes into account the annual distance driven and fuel economy of fleets, based on average or common real-world values. It shows that replacing a transit bus, Class 8 truck, or refuse truck yields much greater emissions reductions than replacing smaller, more efficient vehicles that drive fewer kilometers every year. Taxis use more fuel than delivery trucks or school buses, despite being smaller and more efficient, because they drive more miles. 


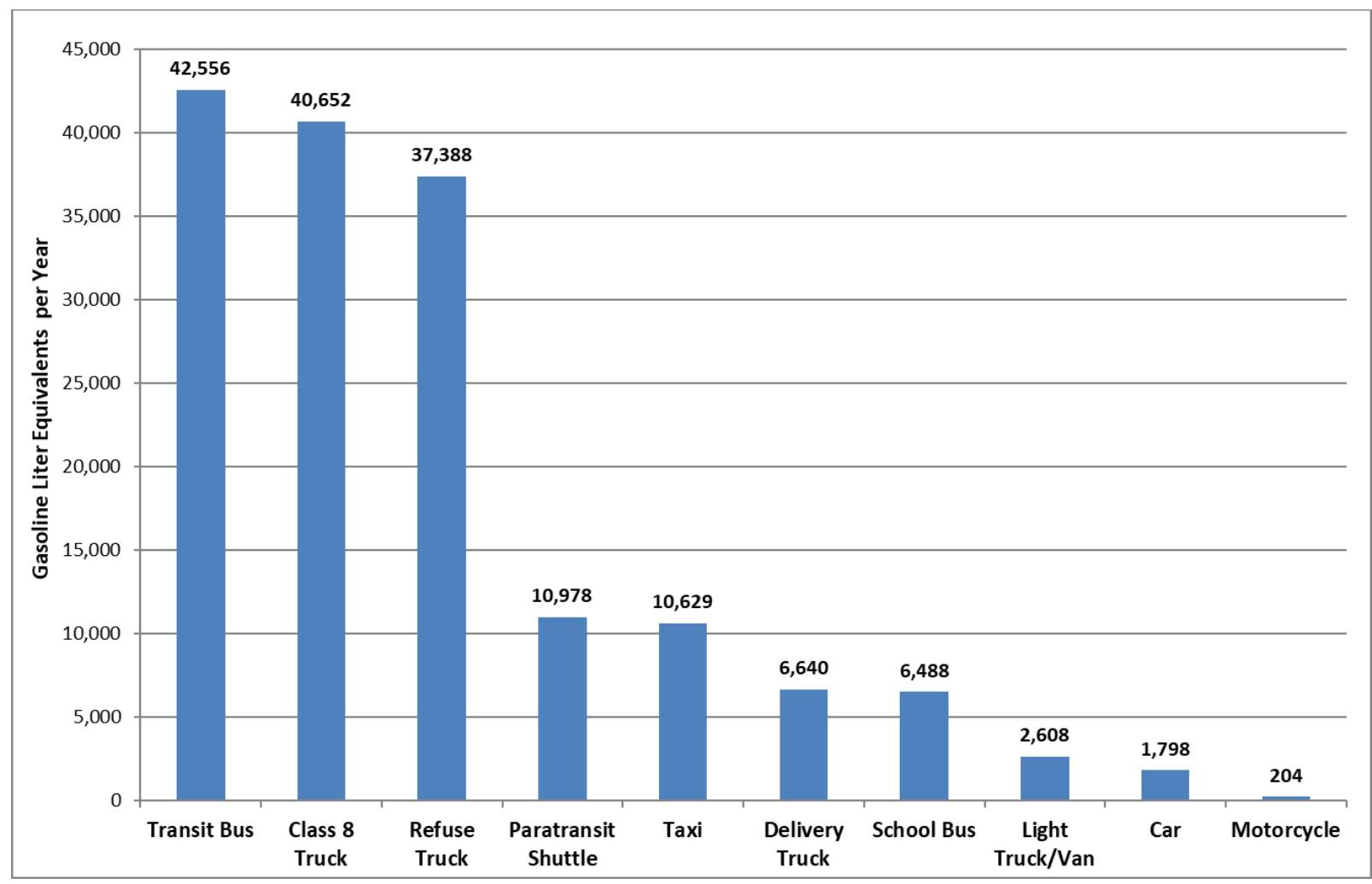

Figure 6. Annual petroleum use of various vehicle types in the United States (Gasoline Liter Equivalents represent both diesel and gasoline)

Source: U.S. DOE EERE 2018a

\subsubsection{Fleet compatibility with electric grid}

Electric fleets can be integrated to the Mexicali grid more easily if they can charge during off-peak or low-demand periods. As shown in Figure 4, this is foremost during the winter, when the electric load in Mexicali is lower and therefore more available capacity exists in the grid. This means that fleets driving longer distances in the winter, such as school buses, are more compatible. Most fleets also operate in the summer, so the daily timing of their charges needs to be taken into account. Fleets that need to charge between 11 a.m and 9 p.m. could be more difficult to incorporate into the grid. This would include many fleets that rely upon fast chargers for quick charges throughout the day. On the other hand, fleets with large ranges that can drive throughout the day and charge overnight (particularly with charge timers or smart EVSE) can recharge without adding to the peak electric load.

In addition to charge timing, charge location also helps determine the compatibility of fleets with the grid. As mentioned in Section 3.2, feeders must have available excess capacity in order to add PEVs at lower cost. Adding this capacity can be expensive. Another strategy could be to work backwards: identify feeders with spare capacity and then determine what vehicles operate in those areas and target them for replacement by PEVs.

\subsubsection{Summary of fleet prioritization}

Table 3 summarizes the various attributes of fleet drive cycles that pair well with PEVs, and the fleets that are likely to display those attributes. These ratings reflect average fleets rather than 
Mexicali-specific fleets and should therefore be considered preliminary (especially grid timing and feeder location). There is no defined method to weight or quantify the benefits of these attributes, but some fleets show up under more categories than others which suggests a greater benefit from PEV adoption. Transit and school bus fleets appear in six out of seven categories, implying that they would benefit from PEVs in numerous ways. Airport ground support equipment fulfils five categories, followed by refuse trucks and taxi fleets with four categories each. It should be noted that there are several attributes that could not be included in the chart because gathering supporting data is beyond the scope of this report. Foremost among these would be annual fuel use and upfront cost of the PEV, which are key determinants of the payback period of a vehicle because the additional upfront cost is paid back through per-mile fuel savings.

Table 3. Fleets That Are Most Compatible with PEVs, by Fleet Attribute

\begin{tabular}{|c|c|c|c|c|c|c|c|}
\hline $\begin{array}{c}\text { Vehicle fleet } \\
\text { type }\end{array}$ & $\begin{array}{c}\text { Electric } \\
\text { vehicle } \\
\text { availability }\end{array}$ & $\begin{array}{c}\text { Compatibility } \\
\text { of routes and } \\
\text { charging } \\
\text { needs }\end{array}$ & High $\mathrm{KI}^{\mathrm{a}}$ & $\begin{array}{c}\text { Idle } \\
\text { reduction } \\
\text { opportunity }\end{array}$ & $\begin{array}{c}\text { Valuation } \\
\text { of } \\
\text { ancillary } \\
\text { benefits }\end{array}$ & $\begin{array}{c}\text { Quantity of } \\
\text { GHGs } \\
\text { emitted }\end{array}$ & $\begin{array}{l}\text { Compatibility } \\
\text { with grid } \\
\text { timing and } \\
\text { feeder } \\
\text { location }\end{array}$ \\
\hline Transit bus & $\square$ & $\square$ & $\square$ & $\square$ & $\nabla$ & $\nabla$ & \\
\hline School bus & $\nabla$ & $\nabla$ & $\nabla$ & $\nabla$ & $\nabla$ & & $\nabla$ \\
\hline $\begin{array}{l}\text { Airport ground } \\
\text { support } \\
\text { equipment }\end{array}$ & $\checkmark$ & $\nabla$ & $\square$ & $\nabla$ & $\nabla$ & & \\
\hline Refuse truck & $\nabla$ & & $\nabla$ & $\nabla$ & & $\nabla$ & \\
\hline Taxi & $\bar{\nabla}$ & & & $\bar{\nabla}$ & $\nabla$ & $\bar{\nabla}$ & \\
\hline Shuttle bus & $\bar{\nabla}$ & $\nabla$ & & $\bar{\nabla}$ & & & \\
\hline Campus/resort & $\bar{\nabla}$ & $\bar{\nabla}$ & & & $\nabla$ & & \\
\hline Delivery truck & $\bar{\square}$ & $\bar{\square}$ & $\checkmark$ & & & & \\
\hline $\begin{array}{l}\text { Bucket/utility } \\
\text { truck }\end{array}$ & $\nabla$ & & & $\checkmark$ & & & \\
\hline Semitrailer & [late 2020] & & & $\nabla$ & & $\nabla$ & \\
\hline \multicolumn{8}{|c|}{$\begin{array}{l}\text { a Some fleets in this category are FleetDNA vocation types rather than vehicle types, and therefore do not appear in } \\
\text { Table } 3 \text {. Taxis are not tracked by FleetDNA and therefore do not appear in the KI column. } \\
\text { b } \\
\text { This column is preliminary and requires follow-on work and an understanding of Mexicali's fleets that this study did } \\
\text { not pursue. Several vocation types might be able to charge overnight starting at } 9 \text { p.m. and therefore be compatible } \\
\text { with grid timing, but fleets and individual vehicles that need to charge during the day are more likely to require feeder }\end{array}$} \\
\hline
\end{tabular}

\subsection{Fleet Incentives}

Once fleets have been prioritized, the odds of them adopting PEVs can be increased by implementing appropriate incentives. Fleets can generally benefit from incentives designed to increase PEV purchases among the general public (Section 6.3). However, there are additional instruments available to specifically target fleets:

Mandates: Municipal governments can mandate municipal fleets to purchase PEVs. It is good to leave as much flexibility as possible in mandates so that fleets can meet them in the most convenient and cost-effective way. Furthermore, one wants to make sure that the mandate does 
not increase the overall distance driven by vehicles as an unintended consequence. Therefore, it is often more productive to mandate a given amount of conventional fuel to be reduced or replaced by electricity rather than mandate specific vehicle purchases. This will allow the fleet to achieve the goal in the most cost-effective way. Another key to successful mandates is to have a long-term goal with multiple near-term steps.

Economic incentives: There are a number of ways that governments incentivize fleets to purchase PEVs and charging equipment. The most straightforward method is providing grants on a competitive basis so that the fleet best posed for success can be chosen. Fleets should compete upon factors that will enable them to successfully utilize PEVs, such as technical expertise, strong partners, and willing drivers. Purchase incentives whereby PEV purchasers can get a tax refund or rebate are also commonly used.

Energy performance contracts: PEVs often have an attractive payback period, but fleets have difficulty finding the money for the upfront investment. Energy performance contracts bridge this gap by providing the upfront investment money that is repaid over time through energy savings.

Waivers to access restrictions: Some cities have access restrictions to certain roads, highoccupancy vehicle lanes, airports, or parking areas. Allowing PEVs to access these restricted areas is often a strong incentive to buy PEVs.

Electricity discounts: Some utilities offer a reduced rate for PEVs. Others offer flexibility on their demand charges. Both of these actions help ensure that the PEV will pay back more quickly.

EVSE requirements in building codes: Building codes can either require EVSE or require that the wiring of a building is sufficient to host an EVSE in the future. This takes advantage of the fact that it is less expensive to wire a building for EVSE when it is being built, than to retrofit it years later when there is EVSE demand. This approach was adopted by European Union as part of the Energy Performance Buildings Directive.

\subsection{Mexicali Taxi Fleet}

Taxis are a promising fleet for electrification, as shown in Table 3 . These attributes, along with the fact that the number of taxis in Mexicali increased nearly 30\% in 2018 alone (City of Mexicali, 2019b) led Mexicali to experiment with electric taxis. However, the fleet has reported some problems with charging inconvenience, compounded by a reduced vehicle range in hot weather conditions. In particular, they reported that during the hottest days (approximately $43^{\circ} \mathrm{C}$ ), their 2017 Nissan Leafs were only achieving half of the expected range.

NREL corroborated these conclusions by comparing the reported electric vehicle performance (for a Nissan Leaf) with prior simulation results performed with very hot ambient temperature assumptions ${ }^{4}$. The reported range reduction is realistic under such extreme temperatures, especially given the taxi drive cycle characterized by idling and slow speeds. The air-cooled

\footnotetext{
${ }^{4}$ Simulations archived in the Fleet Carma database
} 
batteries $^{5}$ of the 2017 Leaf likely performed worse than a liquid-cooled battery would have. In an effort to improve electric taxi performance in the short term, NREL provided some operational strategies for realizing greater range of the existing electric vehicle fleet:

1. Use PEVs in routes with higher speeds and less idling. Vehicle range depends on speed; faster speeds are typically associated with higher powertrain efficacy, resulting in more miles driven for a given charge event. Less idle time translates to less of the charge being used on air conditioning instead of driving.

2. Target downtime in the shade (such as lines to pick up passengers). Spending idle periods in the shade results in less heat from the sun and reduced air-conditioning loads.

3. Add window film for reduced solar radiation experienced by the vehicle cabin, further reducing air-conditioning loads.

4. Consider prioritizing PEV taxi usage during colder days or overnight periods when the ambient temperatures and solar radiation is reduced.

5. Charge the vehicles at lower temperatures, such as within a garage.

6. Consider different PEV makes and models with larger batteries, smaller cabin sizes, or liquid-cooled batteries for increased performance and convenience. Most of these features, plus the manufacturer's suggested retail price, can be found on www.fueleconomy.gov. Longer battery ranges could alleviate much of the driver dissatisfaction even if they do not achieve their rated range in Mexicali conditions.

To facilitate long-term guidance, NREL shipped a vehicle telematics data collection device to be installed on an existing electric vehicle (Nissan Leaf) within the taxi fleet. The data collection device collects utilization information (such as speed, battery state, etc.) and transmits values over a $4 \mathrm{G}$ connection for remote analysis. Data transmitted from the logger revealed real-world performance consistent with complaints from drivers. For instance, a driving event of only $50 \mathrm{~km}$ on a hot day significantly depleted the battery and required pausing a shift early (Figure 7).

\footnotetext{
${ }^{5}$ Vehicle batteries produce heat while in operation and therefore require cooling systems. These systems use either air or liquid.
} 


\section{Vehicle Data, September 23}

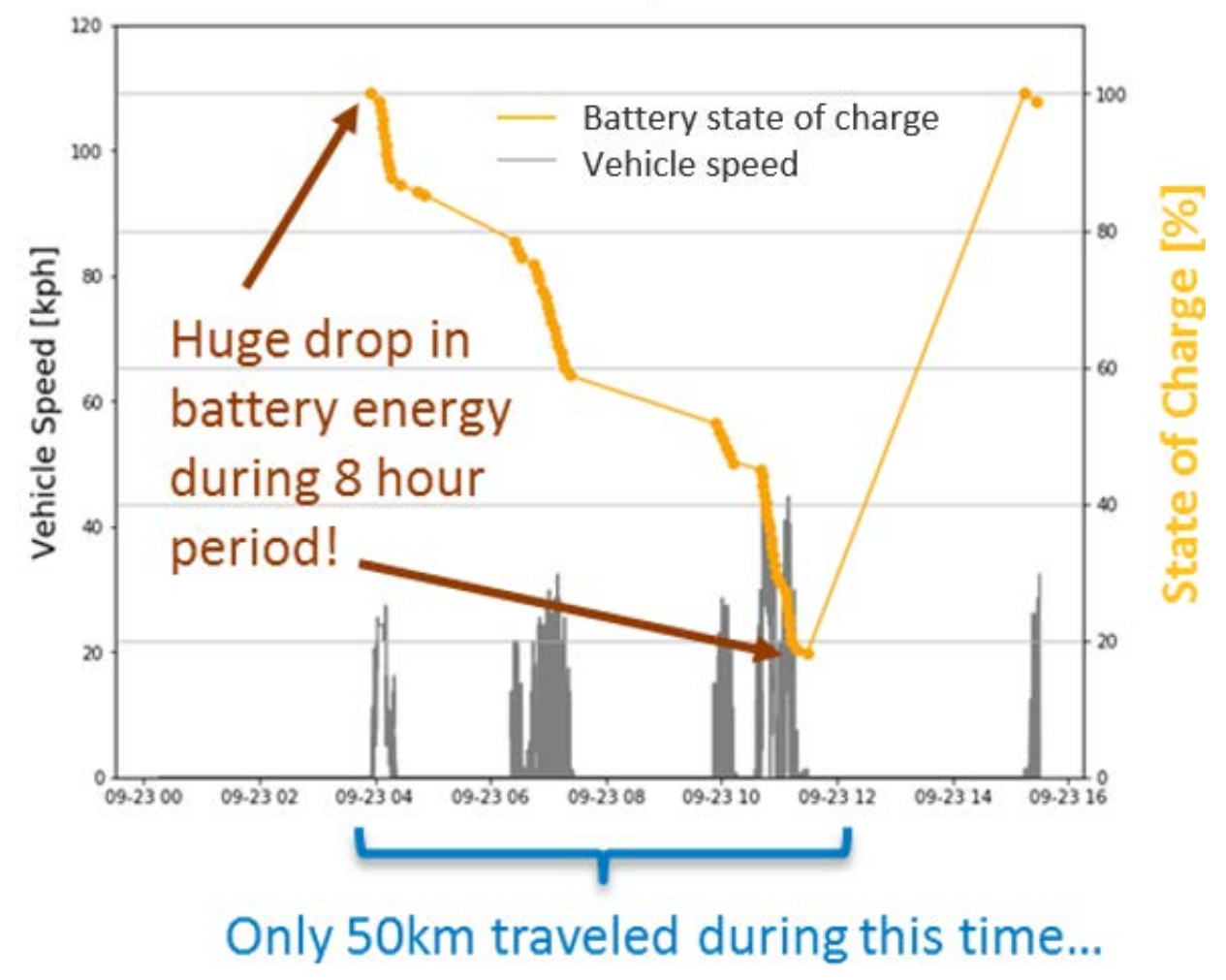

Figure 7. Real-world taxi performance generated and collected under this project from a Nissan Leaf in Mexicali

Although this analysis only included a single vehicle, it demonstrated successful transport of data collection devices to Mexicali from NREL and confirmation that the logger could communicate over a 4G network in Mexico. Figure 8 shows a heat map of where the electric taxi drove most often and spent the most time. Similar tracking of additional taxis could reveal the taxi routes/drivers that would be the most compatible with EV range. Moreover, through this type analysis, NREL could establish a baseline of electric vehicle performance in the city. As the taxi fleet considers purchasing separate electric vehicles with enhanced capabilities (bigger batteries and better battery-cooling strategies), additional loggers may be used to quantity improvements in real-world performance. 


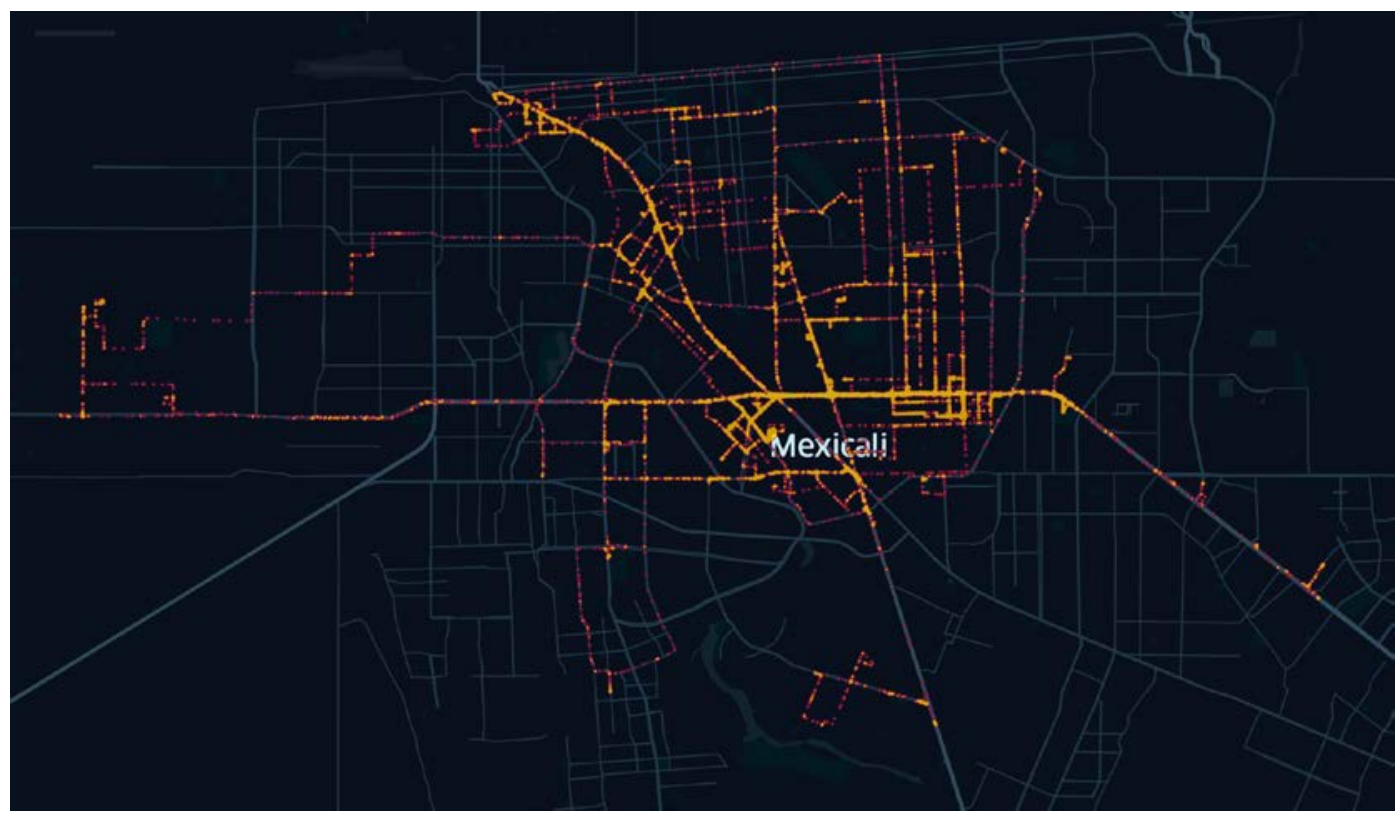

Figure 8. Heat map of electric taxi in Mexicali using data collected under this project

Note: thicker lines indicate routes where the taxi travelled more frequently

\subsection{Electric Mobility and Mass Transit}

Mexicali has prioritized mass transit as a means to improve mobility system efficiency. This prioritization could reduce traffic congestion, traffic deaths, fuel use, and harmful air emissions. Mobility electrification complements mass transit in two main ways. First, electricity is a suitable fuel for buses and trains and has a history of being used in Mexico's transport sector. Mass transit in Mexico is already partially electrified. Trolley buses with catenary lines have been operating in Mexico since 1951 (Fouché 2019) and commuter trains have been electrified since 1887 (Tilling 1952). Adding battery electric buses to this mix can be used to increase route flexibility and reduce infrastructure costs, as described in Section 5 of this report.

One of the largest hurdles to the expansion of mass transit is getting riders to the station from their house, and vice versa, known as the first- and last-kilometer dilemma. Electric mobility complements mass transit by filling this gap. For example, electric scooters and skateboards are proliferating in Mexico City and other cities around the world, in part because they can be carried on public transport easily. Combustion engines and fuel would not be allowed to be transported on most public transit for safety reasons, and would be too heavy, loud, and odorous to drive to many of the places the electric versions go. Smartphone applications such as Bird and Lime are making short-term rentals of these vehicles quick and convenient.

Electric motorcycles and mototaxis are another way that electric vehicles can help solve the firstand last-kilometer dilemma. Gasoline motorcycles and mototaxis are filling this niche in many cities in Mexico, but these vehicles often emit more harmful air pollutants per gallon of gasoline than larger cars because they lack equipment such as catalytic converters (Carpenter 2014). Their main advantage is that they are inexpensive and smaller, so they do not cause as much congestion in transit terminals as an equivalent number of cars. The motorcycle niche could readily be electrified by a number of electric motorbikes and chargers already on the market. Utilizing these 
small electric vehicles instead of their gasoline counterparts could reduce local air pollution in dense transportation hubs and reduce GHG emissions. Charging them at transit hubs or homes in the neighborhood would be an additional advantage for this type of vehicle that typically operates in neighborhoods where there are few refueling stations. Utilizing them instead of cars would reduce bottlenecks at transport hubs because they are smaller.

\section{Expansion to Individual Driver PEV Market}

After fleets have pioneered PEVs in Mexicali and helped develop the required expertise and some charging infrastructure, a next step would be to expand PEV sales to the individual driver market. Three factors have proven to promote sales in this group: adding EVSE, facilitating EVSE system cohesion through standardization, and offering PEV purchase incentives.

\subsection{Charging Infrastructure}

Adding EVSE is an effective way to increase PEV sales. In the United States, specifically, the addition of one charging station per hundred thousand drivers was found to increase PEV purchases by $3.1 \%$ and increase battery electric vehicle purchases (which exclude PHEVs) by 7.2\% (Narassimhan and Johnson 2018). Although most vehicles in the U.S. charge at home (U.S. DOE EERE 2019f), additional EVSE increases PEV sales in part by reducing range anxiety. It is therefore important to place the first public EVSE in areas with high traffic and publicize them well. Private financing can often be leveraged by companies that stand to draw customers through their EVSE. For example, installing EVSE could be a good investment for retail stores because PEV owners would prefer a retailer where they can charge their car and then possibly stay longer than they would have otherwise as their car charges and their purchase of retail goods increases. Many U.S. states and municipalities, in addition to Canada, China, the European Union, and Japan, have incentivized private companies to install and host EVSE by paying for a portion of the equipment (U.S. DOE EERE 2019e, IEA 2019).

The government of Mexicali can also play a role in finding appropriate EVSE hosts and informing them of the potential value of hosting. The companies most likely to profitably host EVSE are retail stores that can increase sales of their products by having a "captive audience" spend additional time at their store while cars are charging. Therefore, these companies could profit indirectly from EVSE even if they do not make money on the electricity sold. Examples of these stores include a variety of retail stores, malls, and grocery stores. Another group of businesses to benefit from hosting EVSE are ones where people are going to spend over half an hour anyway, and they are more attractive to customers if they can charge vehicles while the customer is there. Examples of this category of businesses include restaurants, coffee shops, movies, or gyms. Mexicali could inform businesses that are in good EVSE locations (Figure 10) that they could increase sales by hosting an EVSE.

Beyond financing and facilitating hosts, the government of Mexicali could facilitate the build-out of a cohesive EVSE infrastructure by adopting standards so that all PEVs can use all EVSEs. Table 4 shows standards that are utilized around the world. Since Mexicali is in North America, it would be easiest to get compatible vehicles, equipment, and technicians if they utilized the SAE J1772 for all slow charging. All vehicles intended for the North American market can use this EVSE (including Tesla, which has an adaptor that allows them to use this plug). 
Table 4. Overview of the EVSE Standards Used in Various Regions

\begin{tabular}{|c|c|c|c|c|}
\hline & $\begin{array}{l}\text { Conventional } \\
\text { plugs }\end{array}$ & Slow chargers & \multicolumn{2}{|c|}{ Fast chargers } \\
\hline Level & Level 1 & Level 2 & \multicolumn{2}{|l|}{ Level 3} \\
\hline Current & $\mathrm{AC}$ & $\mathrm{AC}$ & $\begin{array}{l}\text { AC, } \\
\text { Three- } \\
\text { phase }\end{array}$ & DC \\
\hline Power & $\leq 3.7 \mathrm{~kW}$ & $>3.7 \mathrm{~kW}$ and $\leq 22 \mathrm{~kW}$ & $\begin{array}{l}>22 \mathrm{~kW} \\
\text { and } \leq \\
43.5 \mathrm{~kW}\end{array}$ & Currently < 400 kW \\
\hline Australia & Type 1 & IEC 62196-2 Type 2 & & $\begin{array}{l}\text { Accepts all IEC } 62196-3 \text { standards } \\
\text { (CCS Combo 2, CHAdeMO). } \\
\text { Tesla has its own connector. }\end{array}$ \\
\hline China & Type I & $\mathrm{GB} / \mathrm{T} 20234 \mathrm{AC}$ & & Requires GB/T 20234 DC. \\
\hline $\begin{array}{l}\text { European } \\
\text { Economic } \\
\text { Area }\end{array}$ & Type C/F/G & IEC 62196-2 Type 2 & $\begin{array}{l}\text { IEC } 62196-2 \\
\text { Type } 2\end{array}$ & $\begin{array}{l}\text { Requires CCS Combo } 2 \\
\text { (IEC } 62196-3 \text { ) and accepts all IEC } \\
62196-3 \text { standards (including } \\
\text { CHAdeMO). } \\
\text { Tesla has its own connector. }\end{array}$ \\
\hline India & Type C/D/M & $\begin{array}{l}\text { IEC 62196-2 Type } 2 \\
\text { and IEC } 60309 \text { (Bharat } \\
\text { AC-001) }(<10 \mathrm{~kW}) \\
\text { Bharat DC-001 } \\
(<15 \mathrm{~kW})\end{array}$ & $\begin{array}{l}\text { IEC } 62196- \\
2 \text { Type } 2\end{array}$ & $\begin{array}{l}\text { Requires CCS Combo } 2 \text { and } \\
\text { CHAdeMO (IEC 62196-3). }\end{array}$ \\
\hline Japan & Type B & $\begin{array}{l}\text { SAE J1772 Type } 1 \\
\text { Tesla has its own } \\
\text { connector. }\end{array}$ & & $\begin{array}{l}\text { Accepts all IEC } 62196-3 \text { standards } \\
\text { (CCS Combo 1, CHAdeMO). } \\
\text { Tesla has its own connector. }\end{array}$ \\
\hline Korea & Type A/C & IEC 62196-2 Type 2 & & $\begin{array}{l}\text { CCS Combo } 1 \text { (IEC 62196-3) and } \\
\text { accepts all IEC } 62196-3 \text { standards } \\
\text { (including CHAdeMO). } \\
\text { Tesla has its own connector. }\end{array}$ \\
\hline $\begin{array}{l}\text { New } \\
\text { Zealand }\end{array}$ & Type 1 & IEC 62196-2 Type 2 & $\begin{array}{l}\text { IEC } 62196 \\
2 \text { Type } 2\end{array}$ & $\begin{array}{l}\text { Requires CCS Combo } 2 \text { and } \\
\text { CHAdeMO (IEC 62196-3). }\end{array}$ \\
\hline $\begin{array}{l}\text { North } \\
\text { America }\end{array}$ & $\begin{array}{l}\text { Type B: SAE } \\
\text { J1772 Type } 1\end{array}$ & $\begin{array}{l}\text { SAE J1772 Type } 1 \\
\text { Tesla has its own } \\
\text { connector. }\end{array}$ & SAE J3068 & $\begin{array}{l}\text { Accepts CCS Combo } 1 \text { (SAE J1772 } \\
\text { \& IEC 62196-3) and CHAdeMO } \\
\text { (IEC 62196-3). } \\
\text { Tesla has its own connector. }\end{array}$ \\
\hline Singapore & Type G & IEC 62196-2 Type 2 & $\begin{array}{l}\text { IEC } 62196- \\
2 \text { Type } 2\end{array}$ & $\begin{array}{l}\text { Requires CCS Combo } 2 \text { (IEC } \\
62196-3) \text {. }\end{array}$ \\
\hline Thailand & Type A/B/C/F & IEC 62196-2 Type 2 & & $\begin{array}{l}\text { Accepts all IEC } 62196-3 \\
\text { standards (CCS Combo 1, CCS } \\
\text { Combo 2, CHAdeMO). } \\
\text { Tesla has its own connector. }\end{array}$ \\
\hline
\end{tabular}

Source: IEA 2019 
The only major downside of using SAE J1772 for slow charging is that less expensive Chinese PEVs cannot use it. The choice is not as clear for the fast EVSE, of which three have a strong presence in the U.S. markets and are therefore likely to be available in Mexicali. These three are the Combined Charging System Combo, CHAdeMO, and Tesla. The configuration of each is shown in Figure 9, and relative benefits of each are described below.

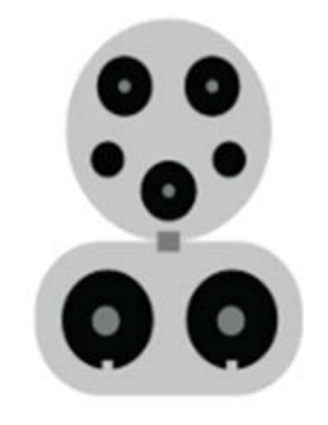

J1772 Combo

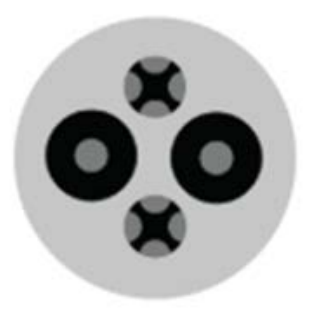

CHAdeMO

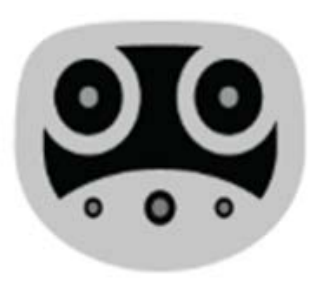

Tesla Combo

Figure 9. Three plug standards in North America

Source: U.S. DOE EERE 2019d

\section{Benefits of Combined Charging System Combo EVSE:}

1. Used by Ford, GM, BMW, Mercedes, VW, and other European manufacturers

2. Protocols compatible with smart grid (Herron 2017) to facilitate future charge-timing coordination

3. Only one charge port on the vehicle is necessary for fast and slow charge, making it more attractive to auto manufacturers

4. Can be used for buses and trucks (CharIN 2018), therefore possibly leveraging heavy-duty vehicle infrastructure

\section{Benefits of CHAdeMO:}

1. Used by Nissan and Mitsubishi in Japan

2. Tesla vehicles can use, with an adaptor

3. Capable of exporting power from vehicles to buildings or directly to the electric grid

4. Most ubiquitous EVSE in the United States (available at 2,852 unique locations [U.S. DOE EERE 2019e] but losing ground to Combined Charging System [2,651 locations] and Tesla [784 locations])

\section{Benefits of Tesla}

1. Tesla might install for free, if they deem the market promising enough

2. Only one charge port on the vehicle necessary for fast and slow charge (similar to Combined Charging System Combo). 


\subsection{Charging Station Location Analysis}

Charging stations must be well located in order to serve the most PEVs in the most convenient way possible. NREL worked with Mexicali to conduct a charging station location analysis to identify optimal siting of public EVSE while taking into account traffic patterns, PEV ownership demographics, local economics, local incentives, and the impact that visible EVSE has on range anxiety, and therefore PEV purchases. The analysis relied on several data sets provided by the Mexicali government to conduct a geospatial multi-criteria decision analysis (MCDA) that locates optimal areas for public EVSE.

The following section describes input data, methods, and assumptions.

\subsubsection{Data and Methods}

\section{Road Network \& Data}

The City of Mexicali provided a current road network shapefile for the area of interest. These road network data contain an attribute that distinguishes primary and secondary roads. This data parameter is the best available proxy for road usage and traffic patterns.

A key requirement for the EVSE location is proximity to high-traffic areas, while also being visible from the road for drivers to see and easily access. The provided road data do not include any direct traffic information such as segment-level average traffic counts, nor were any trip origindestination or GPS data provided. As such, the best proxy to this information is road classification. Secondary roads were selected because they are major roads but typically at ground level and easily accessible to drivers, while also easily exited. Primary roads were omitted from the analysis as they are typically more limited in access, require on- and off-ramps, elevated from ground level, and more likely out of visible range of possible PEV charging stations. An 80-meter buffer was generated around all secondary roads in Mexicali, as this is an intuitive visible range for most drivers.

\section{Land Use}

A vectorized land-use data set was also provided. This data set describes the land use types of the Mexicali area, with designations such as commercial, conservation, housing, industrial, and so on.

The primary way in which the land-use data were utilized was to identify suitable areas for public EVSE installation. Several land-use types were selected for the analysis. These areas include commercial areas, services areas, and urban corridors given presumed consistent traffic while also being open to publicly available EVSE installation, such as EVSE installation in business parking spaces or public parking areas. Many land-use areas, ranging from conservation areas, barrens, industrial areas, and housing areas, were not selected in this analysis as these land-use types are either not conducive to heavy traffic or public works installations.

\section{Census Data}

Lastly, Mexican census block-level data were provided by Mexicali. These data describe the blocklevel population data, such as total population, total housing, occupancy, vehicle ownership, and more. No income data was included in this data set. 
Census data were sought for demographic and economic information. Particularly, household income is the most important parameter that is often used to predict EVSE needs, as it is a key indicator of residents' abilities to purchase EVs (Narassimhan and Johnson 2018). However, Mexicali was unable to provide direct household income information. The total-vehicle-percensus-block data parameter was initially used as a proxy for income under the assumption that vehicle ownership implies higher income. However, through testing of different ownership rates, this parameter proved to be too limiting for the overall MCDA. For this reason, the provided census data were not used in the analysis.

\subsubsection{Results}

Figure 10 shows the output of the geospatial MCDA.

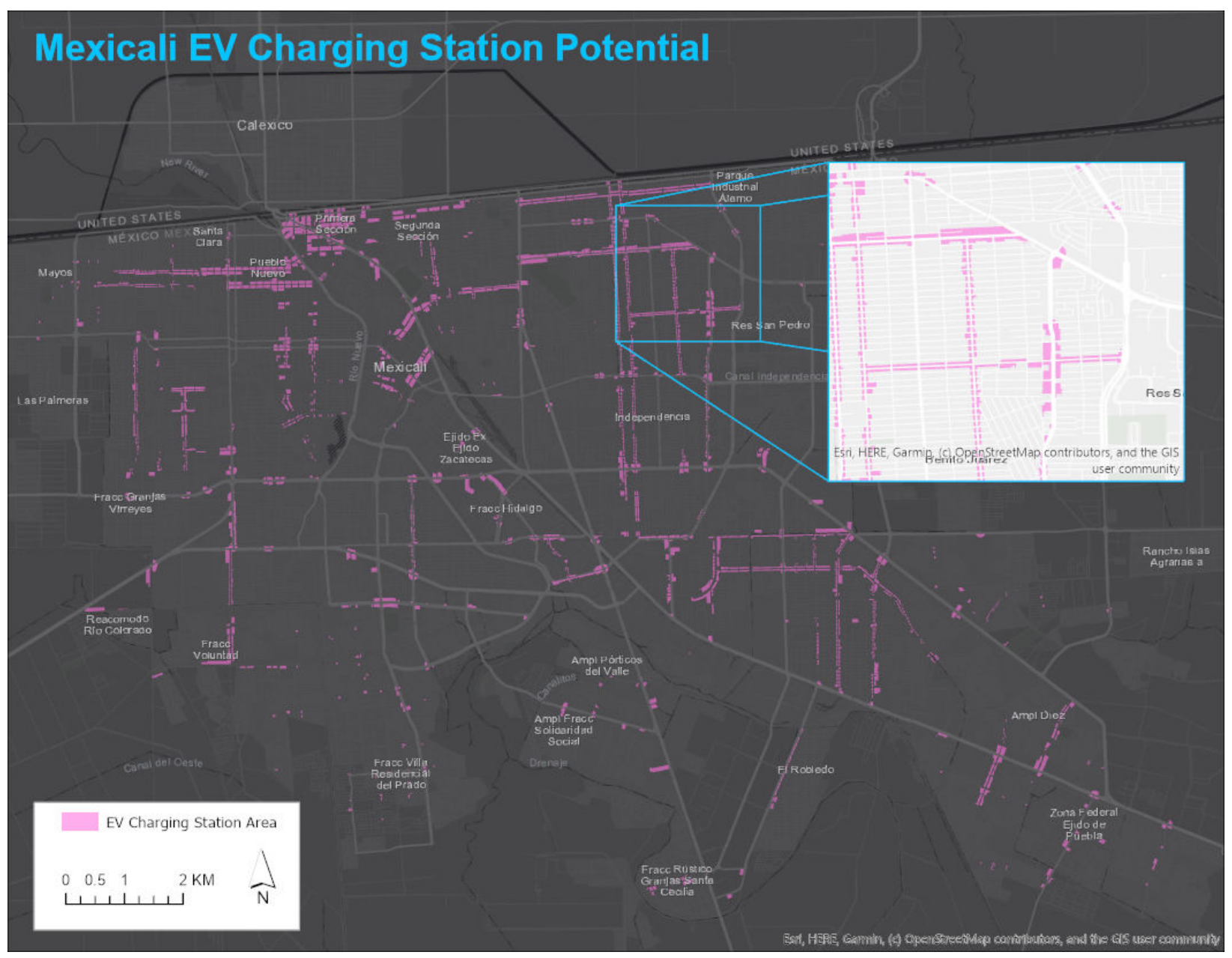

Figure 10. Mexicali potential public EVSE infrastructure

As shown in Figure 10, MCDA results indicate that Mexicali has many areas throughout the city that have potential for public EVSE installation. This implies Mexicali has a lot of flexibility in where they site EVSE because there are suitable sites throughout the city. However, based on the general nature of the input data used, it is likely that some of the areas shown in the map may be suboptimal for EVSE installation (see Limitations \& Areas for Improvement). 


\subsubsection{Limitations \& Areas for Improvement}

The original goal of this MCDA was to identify areas where public EVSE can be implemented utilizing traffic patterns, PEV ownership demographics, local economics, and local incentives. These inputs should be included while also accounting for the impact that visible EVSE has on range anxiety, and therefore PEV purchases. Many of these parameters are not directly included in the provided spatial data. As such, the provided data were used to ascertain proxies for the above inputs.

The limiting factor of the performed MCDA is the available input data. Input data sets were generally used as approximations for the ideal data inputs of traffic, demographics, and economics. The provided data did not contain highly specific information about any of these parameters, so it was used to infer instead. This led to a generalized analysis, showing many possible areas of EVSE potential. The following sections discuss improvements that can be made for the input data to better refine the analysis.

\section{Travel Data}

The binary primary and secondary road classifications are often poor indicators of actual road use and travel patterns because they do not account for many factors such as vehicle kilometers traveled, average annual daily traffic, or congestion. Road classification can imply this information, but several spatial and temporal factors must be taken into account. The best data sets that provide travel information are GPS travel data or origin-destination trip data. GPS travel data provide ground-truth insight into how the population travels, including when they travel, which routes are taken, and which roads have the most traffic. Origin-destination data do not provide this level of detail but do give insight on where residents travel often and where they come from. This can be used to infer likely routes of high traffic for optimal EVSE installation. Finally, a good alternative to identify areas of heavy traffic if GPS or trip data are unavailable is a road network with segment-level average annual daily traffic, vehicle kilometers traveled, or similar traffic data.

\section{EV Incentive and Other Geographic Data}

The land-use data that were provided were granular enough to give good insight into EVSE location based on the likely traffic of the area. This was largely confined to businesses and urban corridors. However, the data provided by the City of Mexicali did not contain any spatially referenced PEV incentive data. This could include information on which types of businesses or other land-use areas may receive any government incentives to install EVSE. Inclusion of these data could refine the analysis to be more limiting with respect to potential EVSE installation areas by ruling out businesses or urban areas that are less incentive to provide this service. Lastly, other geographic information, such as local regulations, parking availability, potential host companies, and so on were not included. Each of these layers could potentially better refine the analysis in their own way.

\section{Income Data and Vehicle Registration Data}

Finally, the census data provided were ultimately left out of the analysis. A key variable for the population with respect to PEV adoption is income (Narassimhan and Johnson 2018). However, no income information was included with the census data provided by the City of Mexicali. Other 
variables, such as households with vehicles, were initially tested as a replacement option, but this proved to be too limiting for the analysis. Having access to income data for the population would better refine the analysis. Lastly, local vehicle registration data would give direct information about the portion of the population that has access to EVs, and where they reside.

\subsubsection{Geospatial Analysis Conclusion}

The MCDA analysis incorporated various layers of data (e.g. land use, road network, census block group) provided by the City of Mexicali. Figure 10 shows the output of this analysis, which reveals a wide coverage of potential public EVSE locations across Mexicali. The quality of input data may skew these results; improved data as outlined above would yield more accurate results.

\subsection{PEV Purchase Incentives}

In addition to EVSE access, purchase incentives have proven to be an effective way to spur a PEV market. Table 5 shows how effective various state-level purchase incentives were in the United States at incentivizing people to purchase PEVs. One of the most impactful is granting access to high-occupancy vehicle lanes. If a state granted such access, it correlated with an $8.5 \%$ increase in PEV purchases and a $14.5 \%$ increase in battery electric vehicle purchases. Another impactful incentive is a sales tax waiver, which led to a 3.6\% increase in PEV purchases for every $\$ 1,000$ spent on the waiver. The waiver has a greater impact than an income tax credit or rebate because the purchaser sees the benefit immediately. Examples of tax waivers enacted by U.S. states can be accessed at the Alternative Fuels Data Center Laws and Incentives website (U.S. DOE EERE 2019e). Another widely utilized incentive is preferential parking. Placing Level II EVSE at preferred parking spots and banning conventional vehicles from parking there could also substantially increase PEV purchases. 
Table 5. Efficacy of Electric Vehicle Purchase Incentives in the United States

\begin{tabular}{|c|c|c|c|c|}
\hline \multicolumn{5}{|l|}{ State Level Correlation of PEV } \\
\hline Market Variables on Per & & PEV & PHEV & BEV \\
\hline Explanatory Variables & $\begin{array}{c}\text { Increase/Decrease } \\
\text { by }\end{array}$ & $\begin{array}{c}\text { Increases } \\
\text { purchases } \\
\text { by }\end{array}$ & Increases purchases by & Increases purchases by \\
\hline $\begin{array}{l}\text { Charging stations per hundred } \\
\text { thousand population }\end{array}$ & 1 & $3.1 \%$ & $2.6 \%$ & $7.2 \%$ \\
\hline Tax credit (in dollars) & $\$ 1000$ & $2.3 \%$ & Not significant & $5.3 \%$ \\
\hline Rebate (in dollars) & $\$ 1000$ & $4.8 \%$ & Not significant & $7.7 \%$ \\
\hline Sales tax waiver (in dollars) & $\$ 1000$ & $3.6 \%$ & $\begin{array}{l}\text { Not significant overall; } 1.6 \% \\
\text { for Volt }\end{array}$ & $5.9 \%$ \\
\hline $\begin{array}{l}\text { HOV Lane Exemption (Yes or } \\
\text { No) }\end{array}$ & if Yes & $8.5 \%$ & $8.4 \%$ & $14.5 \%$ \\
\hline Home EVSE credit & If Yes & $\begin{array}{c}\text { Not } \\
\text { significant }\end{array}$ & $\begin{array}{l}\text { Not significant overall; } 26.0 \% \\
\text { for Volt }\end{array}$ & Not significant \\
\hline Home charging discount & If Yes & $\begin{array}{c}\text { Not } \\
\text { significant }\end{array}$ & Not significant & Not significant \\
\hline Gasoline price & $1 \%$ & $0.6 \%$ & $0.5 \%$ & $0.8 \%$ \\
\hline $\begin{array}{l}\text { Environmental awareness } \\
\text { (based on LCV house scores) }\end{array}$ & 1-point increase & $\begin{array}{l}\text { Not } \\
\text { significant }\end{array}$ & $\begin{array}{l}\text { Not significant overall; } 0.1 \% \\
\text { for Volt and } 0.2 \% \text { for Prius }\end{array}$ & $\begin{array}{l}\text { Not significant overall; } 0.1 \% \\
\quad \text { for Tesla Model S }\end{array}$ \\
\hline Median Household Income & $1 \%$ & $0.3 \%$ & $0.4 \%$ & $0.5 \%$ \\
\hline Unemployment rate & $1 \%$ & $\begin{array}{c}\text { Not } \\
\text { significant }\end{array}$ & Not significant & Not significant \\
\hline $\begin{array}{c}\text { Vehicle miles traveled per } \\
\text { capita }\end{array}$ & $1 \%$ & $\begin{array}{c}\text { Not } \\
\text { significant }\end{array}$ & Not significant & Not significant \\
\hline
\end{tabular}

Source: Narassimhan and Johnson 2018

Note: LCF stands for League of Conservation Voters

\subsection{Equity Issues}

Incentivizing the purchase of electric vehicles runs the risk of being inequitable by channeling taxpayer funds to wealthy residents more able to afford these vehicles. Inequity issues can be mitigated or countered in a number of ways. Steps taken to improve mass transit and make it more accessible (discussed in Section 4) will primarily benefit transit riders, who in the United States tend to be in the lower income brackets (U.S. DOT FHWA 2019). Therefore, efforts to bolster public transport through electrification helps address the concern of electrification-related funds being directed towards the wealthy. Second, if high-occupancy vehicle lanes are created in order to exempt PEVs, people that carpool will be the co-beneficiaries. Carpooling has been negatively correlated to personal income in the United States (MIT 2009), so any such efforts will increase the equity of the electrification plan. Finally, efforts must be made to add EVSE to underserved communities. This way they will not be excluded from the transport fuel of the future.

\section{Capacity Building and Training}

PEVs and related infrastructure require experts in order to keep them operational, charged, and safe. This requires training a workforce of PEV repair technicians, EVSE installation electricians, and first responders to emergencies involving PEVs or EVSE. 


\subsection{Electric Vehicle Repair Technicians}

Access to PEV repair technicians is an important consideration before purchasing a PEV. To develop a trained PEV technician workforce, Mexicali could consider:

1. Leveraging the technician assistance provided by fleet vehicle manufacturers. When an agency purchases PEVs from a manufacturer, the purchasing contract typically includes a specific number of training hours. When Mexicali receives its electric buses, it could consider inviting more than just the transit agency technicians to the training. Technicians from some of the larger repair shops in Mexicali could also be included, in addition to technicians that specialize in private buses since the bus-specific information will be more relevant to them. Technicians from local technical schools could also be included.

2. Vehicle dealerships could have their manufacturer train dealership technicians. Such training would open the Mexicali market to both PEVs and HEVs. Some manufacturers offer condensed technician training and scholarships. Tesla's START program (Tesla 2019) and Toyota's Tajimi Service Center (Toyota 2014) are two such examples.

3. Finally, if manufacturer resources cannot be utilized through PEV bus purchases or PEV dealerships, the government of Mexicali could sponsor a local technician to go to a PEV technician certification program. One such program is run by the Clean Tech Institute (Clean Tech Institute 2017).

\subsection{EVSE Installation Electricians}

EVSE should only be installed by certified electricians. In addition, some EVSE networks such as ChargePoint have installer certification programs for Level 2 EVSE (ChargePoint 2019). Directcurrent fast chargers are often installed and maintained by the equipment manufacturer as part of the purchase agreement.

\subsection{First Responders}

When a PEV gets in an accident, their high voltage can pose unique safety hazards to drivers and first responders such as fire services and emergency medical services. Therefore, it is important that first responders be trained to deal with PEV accidents. The National Fire Protection Association is the authority on this topic in the United States, and offers a series of associated trainings, events, and guides (NFPA 2019).

\section{Conclusions and Next Steps}

The Municipality of Mexicali, along with its stakeholders and partners, can make meaningful and rapid progress toward the electrification of its mobility sector. This can be done with a variety of approaches, including working with suitable fleets to adopt PEVs and deploying EVSEs, expanding upon fleet EVSE infrastructure to accommodate individual drivers, incentivizing individual drivers to purchase PEVs, balancing the new electricity demand on the grid both spatially and temporally, and training the appropriate mechanics and first responders to work on PEVs. By taking these actions, Mexicali can help meet the environmental, energy, and mobilityrelated goals of Mexicali, Baja California, and Mexico. This report lays the foundation for such a strategy by providing the city with options to select from, based on their priorities. In addition to 
the considerations outlined in this report, some further analyses to refine Mexicali's electromobility strategy are needed. These include:

1. Assessment of the feeders of the Mexicali distribution grid to determine which areas can accept additional electric load without costly improvements

2. Selection of the most appropriate fleets to electrify to pilot the concept

3. Drive cycle analysis of fleet vehicles to help determine the most appropriate PEVs to purchase and the best locations to place EVSE

4. Economic analysis for fleets and EVSE hosts to determine the payback of PEVs

5. Conduct a household mobility survey that helps determine which electrified mobility options would be most effective in encouraging the citizens of Mexicali to ride mass transit, e-bikes, e-scooters, and to carpool

6. Find and incorporate geographical data such as parking availability, potential EVSE host companies, garages, and demographic information into EVSE planning maps

7. Promote the design of incentives and general public management strategies to accelerate the adoption of electric technologies into the city mobility system

8. Many recommendations in this strategy document can be adjusted and replicated in other cities of the region to increase the PEV benefits. 


\section{References}

Carpenter, Susan. (September 16, 2014). Motorcycles and emissions: The surprising facts. Los Angeles Times. www.latimes.com/news/la-hy-throttle11-2008jun11-story.html

ChargePoint. 2019. "Become a Certified ChargePoint Installer." Accessed December 17, 2019. https:/www.chargepoint.com/partners/installers/.

CharIN. 2018. "CharIN Implementation Guide for Plug and Charge based on ISO 15118 published." April 8, 2019. Accessed December 17, 2019. www.charinev.org/news/news-detail2018/news/charin-implementation-guide-for-plug-andcharge-based-on-iso-15118-published/.

Choudhary, A., S. Gokhale, A. Shukla, P. Kumar, and A. K. Singh. "Variability in Emission Rate of Auto-Rickshaw Based on Real World Driving Profile: A Case Study in Guwahati City." In 2019 URSI Asia-Pacific Radio Science Conference (AP-RASC), New Delhi, India, March 9-15, 2019. https://doi.org/10.23919/URSIAP-RASC.2019.8738673.

City of Mexicali. 2019a. Generation de Energia por Tipo de Technologia. Delivered via personal communication with Adriana Macias on April 30, 2019.

City of Mexicali. 2019b. Meeting with city officials and representatives and taxi fleet managers. July 24, 2019.

Clean Tech Institute. 2017. "Certified Electric Vehicle Technician (CEVT) Training Program." Accessed December 17, 2019. www.cleantechinstitute.org/Training/CEVT.html.

Daniels, Lynn and Brendan O’Donnell. 2019. "Seattle City Light: Transportation Electrification Strategy Report.” Rocky Mountain Institute. Accessed December 16, 2019. https://rmi.org/insight/seattle-city-light/.

Eid, Cherrelle, Elta Koliou, Mercedes Valles, Javier Reneses, and Rudi Hakvoort. 2016. "Timebased pricing and electricity demand response: Existing barriers and next steps." Utilities Policy 40: 15-25. https://doi.org/10.1016/j.jup.2016.04.001.

Energy Star. 2013. ENERGY STAR Market and Industry Scoping Report: EVSE. Accessed January $27,2020$.

www.energystar.gov/sites/default/files/asset/document/Electric_Vehicle_Scoping_Report.pdf

eTUK. 2017. "The First Street Legal, Electric Tuk Tuks in the United States." February 23, 2107. Accessed December 16, 2019. http://etukusa.com/press-media/the-first-street-legalelectric-tuk-tuks-in-the-united-states/.

Fouché, Guillaume. 2019. Electric Vehicles in Latin America. Bloomberg NEF.

Gobierno de la República. 2013. "Estrategia Nacional de Cambio Climático: Visión 10-20-40." Accessed December 16, 2019. www.gob.mx/cms/uploads/attachment/file/41978/EstrategiaNacional-Cambio-Climatico-2013.pdf. 
Grütter, Jürg M. and Ki-Joon Kim. 2019. "E-Mobility Options for ADB Developing Member Countries." Asian Development Bank. March 2019. http://dx.doi.org/10.22617/WPS190075-2.

Herron, David. 2017. "EV DC Fast Charging standards - CHAdeMO, CCS, SAE Combo, Tesla Supercharger, etc.” Accessed December 16, 2019. https://greentransportation.info/evcharging/range-confidence/chap8-tech/ev-dc-fast-charging-standards-chademo-ccs-sae-combotesla-supercharger-etc.html.

Hodge, Cabell. 2017. Aligning PEV Charging Times with Electricity Supply and Demand. Golden, CO: National Renewable Energy Laboratory. NREL/TP-5400-68623. http://doi.org/10.2172/1364027.

Hughes, Justin. 2018. "Neighborhood Electric Vehicles: A Different Kind of Electric Car." March 27, 2018. Accessed December 16, 2019. www.thedrive.com/tech/19658/neighborhoodelectric-vehicles-a-different-kind-of-electric-car.

International Energy Agency (IEA). 2019. Global EV Outlook 2019: Scaling-up the transition to electric mobility. Paris: OECD Publishing.

International Transportation Forum (ITF). 2015. ITF Transport Outlook 2015. Paris: OECD Publishing. Accessed December 16, 2019. https://dx.doi.org/10.1787/9789282107782-en.

Iversen, Lykke. 2015. "Measurement of noise from electrical vehicles and internal combustion engine vehicles under urban driving conditions." June 12, 2015. Accessed December 16, 2019. www.toi.no/getfile.php/1340825/mmarkiv/Forside\%202015/compett-foredrag/Lykke\%20Silent $\% 20$ Urban $\% 20$ Driving.pdf.

Massachusetts Institute of Technology (MIT). 2009. “MIT 'Real-Time' Rideshare Research: Personal Income and Carpool Mode Share.” Last updated February 24, 2009. Accessed December 17, 2019. https://ridesharechoices.scripts.mit.edu/home/2009/02/personal-incomeand-carpool-mode-share/.

Ministry of Environment and Natural Resources and National Institute of Ecology and Climate Change (SEMARNAT-INECC). 2016. Mexico's Climate Change Mid-Century Strategy. Mexico City: SEMARNAT. Accessed December 16, 2019. https://unfccc.int/files/focus/longterm strategies/application/pdf/mexico mos final cop22nov16 red.pdf.

Myers, Erika. 2019. A Comprehensive Guide to Electric Vehicle Managed Charging. Smart Electric Power Alliance.

Narassimhan, Easwaran and Caley Johnson. 2018. "The role of demand-side incentives and charging infrastructure on plug-in electric vehicle adoption: analysis of US States." Environmental Research Letters 13, no. 7. https://doi.org/10.1088/1748-9326/aad0f8.

National Fire Protection Association (NFPA). 2019. "NFPA's Alternative Fuel Vehicles Safety Training." Accessed December 17, 2019. www.nfpa.org/Training-and-Events/By-topic/ Alternative-Fuel-Vehicle-Safety-Training. 
National Renewable Energy Laboratory (NREL). 2019. "Fleet DNA: Commercial Fleet Vehicle Operating Data." Accessed December 16, 2019. www.nrel.gov/transportation/fleettest-fleetdna.html.

Netherlands Enterprise Agency. 2019. Electric Vehicles in Mexico. The Hague, Netherlands: Netherlands Enterprise Agency. Accessed December 16, 2019. https://www.rvo.nl/sites/default/files/2019/05/electric-vehicles-in-mexico.pdf.

Secretaría de Energía (SENER). 2016. Prospectiva de Energías Renovables: 2016-2030. Mexico City: Secretaría de Energía. Accessed December 16, 2019. www.gob.mx/cms/uploads/ attachment/file/177622/Prospectiva_de_Energ_as_Renovables_2016-2030.pdf.

Singer, Mark. 2019. "Electric Mobility Showcases: Participant Surveys.” June 18, 2019. Accessed December 16, 2019. https://roadmapforth.org/program/presentations19/ MarkSinger.pdf.

Smart, John, Thomas Bradley, and Shawn Salisbury. 2014. "Actual Versus Estimated Utility Factor of a Large Set of Privately Owned Chevrolet Volts.” SAE International Journal of Alternative Powertrains 3, no. 1: 30-35.

Tesla. 2019. "Tesla START: Student Automotive Technician Program.” Accessed December 17, 2019. https://www.tesla.com/careers/tesla-start.

Haut, F.J.G. 1952. The Early History of the Electric Locomotive. The University of Michigan. ASIN B0007JJNNE.

Timmers, Victor R. J. H. and Peter A. J. Achten. 2016. "Non-exhaust PM emissions from electric vehicles." Atmospheric Environment 147: 10-17. https://doi.org/10.1016/ j.atmosenv.2016.03.017.

Toyota. 2014. "Tajimi Service Centre - where world-class Toyota mechanics are trained." February 20, 2014. Accessed December 17, 2019. http://blog.toyota.co.uk/tajimi-service-centrewhere-world-class-toyota-mechanics-are-trained.

United Nations Development Programme (UNDP). 2015. "Sixth National Communication to the UNFCCC.” Accessed December 16, 2019. https://info.undp.org/docs/pdc/Documents/ MEX/Prodoc\%206CN.pdf.

U.S. Department of Energy Office of Energy Efficiency and Renewable Energy (DOE EERE). 2018a. "Average Annual Fuel Use by Vehicle Type.” Accessed December 16, 2019. https://afdc.energy.gov/data/10308.

- 2018b. "U.S. Plug-in Electric Vehicle Sales by Model." Accessed December 16, 2019. https://afdc.energy.gov/data/10567.

_. 2019a. “All-Electric Vehicles.” Accessed December 16, 2019. www.fueleconomy.gov/feg/evtech.shtml. 
- 2019b. "Alternative Fuels Data Center: Alternative Fuel and Advanced Vehicle Search." Accessed December 16, 2019. https://afdc.energy.gov/vehicles/search/.

—. 2019c. "Alternative Fuels Data Center: Alternative Fueling Station Locator." Accessed December 16, 2019. www.afdc.energy.gov/stations.

- 2019d. "Alternative Fuels Data Center: Developing Infrastructure to Charge Plug-In Electric Vehicles.”

- 2019e. "Alternative Fuels Data Center: State Laws and Incentives.” Accessed December 16, 2019. https://afdc.energy.gov/laws/state.

—. 2019f. “Charging at Home.” Accessed December 16, 2019. https://www.energy.gov/ eere/electricvehicles/charging-home.

U.S. Department of Transportation Federal Highway Administration (DOT FHWA). 2019.

"Transit Trend Analysis: 2017 National Household Travel Survey.” February 2019. Accessed December 17, 2019. https://nhts.ornl.gov/assets/FHWA_NHTS_Report 3A_Final 021119.pdf.

U.S. Energy Information Administration (EIA). 2018. “Table 8.2: Average Tested Heat Rates by Prime Mover and Energy Source, 2008-2018.” Accessed December 16, 2019. www.eia.gov/electricity/annual/html/epa 08 02.html.

U.S. Environmental Protection Agency. 2018. Center for Corporate Climate Leadership Emissions for GHG Inventories. Accessed January 27, 2020.

www.epa.gov/sites/production/files/2018-03/documents/emission-factors mar 2018 0.pdf

Wang, Michael, Amgad Elgowainy, Pahola Thathiana Benavides, Andrew Burnham, Hao Cai, Qiang Dai, Troy Robert Hawkins et al. Summary of Expansions and Updates in GREET® 2018. No. AN1-18/23. Argonne National Lab, Argonne, IL (United States), 2018. 